\title{
Cell-Type Specific Channelopathies in the Prefrontal Cortex of the fmr1-/y Mouse Model of Fragile X Syndrome $e^{1,2,3}$
}

\author{
Brian E. Kalmbach, ${ }^{-}$Daniel Johnston, and Darrin H. Brager
}

DOI:http://dx.doi.org/10.1523/ENEURO.0114-15.2015

Center for Learning and Memory, The University of Texas at Austin, C7000, Austin, Texas 78712

\begin{abstract}
Fragile $X$ syndrome (FXS) is caused by transcriptional silencing of the fmr1 gene resulting in the loss of fragile $X$ mental retardation protein (FMRP) expression. FXS patients display several behavioral phenotypes associated with prefrontal cortex (PFC) dysfunction. Voltage-gated ion channels, some of which are regulated by FMRP, heavily influence PFC neuron function. Although there is evidence for brain region-specific alterations to the function a single type of ion channel in FXS, it is unclear whether subtypes of principal neurons within a brain region are affected uniformly. We tested for alterations to ion channels critical in regulating neural excitability in two subtypes of prefrontal L5 pyramidal neurons. Using somatic and dendritic patch-clamp recordings, we provide evidence that the functional expression of h-channels $\left(I_{\mathrm{h}}\right)$ is down-regulated, whereas A-type $\mathrm{K}^{+}$channel function is up-regulated in pyramidal tract-projecting (PT) neurons in the fmr1-/y mouse PFC. This is the opposite pattern of results from published findings from hippocampus where $I_{\mathrm{h}}$ is up-regulated and A-type $\mathrm{K}^{+}$channel function is down-regulated. Additionally, we find that somatic Kv1-mediated current is down-regulated, resulting in increased excitability of fmr1-/y PT neurons. Importantly, these $\mathrm{h}-$ and $\mathrm{K}^{+}$channel differences do not extend to neighboring intratelencephalic-projecting neurons. Thus, the absence of FMRP has divergent effects on the function of individual types of ion channels not only between brain regions, but also variable effects across cell types within the same brain region. Given the importance of ion channels in regulating neural circuits, these results suggest cell-type-specific phenotypes for the disease.
\end{abstract}

Key words: dendrite; excitability; fragile X syndrome; ion channel; prefrontal cortex

\section{Significance Statement}

Voltage-gated ion channels regulate the excitability of neurons and are altered in fragile $X$ syndrome (FXS), the most common form of inherited mental retardation. In the fmr1-/y mouse model of FXS, we found neuron-type-specific alterations in the function of a group of ion channels within the prefrontal cortex, a brain region associated with many cognitive deficits in FXS. Because of these alterations, neurons with subcortical projections display enhanced excitability while those without subcortical projections do not. This finding highlights the need to understand FXS and tailor its treatment in a cell-type-specific manner.

\section{Introduction}

Fragile $X$ syndrome $(F X S)$ is the most common form of inherited mental retardation and the leading identified

\footnotetext{
Received September 24, 2015; accepted October 28, 2015; First published November 04, 2015.

${ }^{1}$ The authors report no conflict of interest.

${ }^{2}$ Contributions: B.E.K., D.J., and D.H.B. designed the research; B.E.K. and
}

D.H.B. performed the research; B.E.K. and D.H.B. analyzed data; B.K., D.J., and D.H.B. wrote the paper.

${ }^{3}$ This work was supported by National Institutes of Health Grants R01 MH094839 (D.J.), R01 MH100510 (D.H.B.), F32 MH090694 (B.E.K.), and a FRAXA research grant (D.H.B.). We thank Komal Parikh and William Taylor for their assistance with surgery, and R. Chitwood and N. Desai for their thoughtful comments on earlier versions of this paper. 
monogenic cause of autism. Fragile $X$ mental retardation protein (FMRP), the protein absent in FXS, regulates neuron function via multiple mechanisms, including proteinprotein interactions, translational control, and protein trafficking (Hagerman et al., 2005; Bhakar et al., 2012; Santoro et al., 2012; Brager and Johnston, 2014). FMRP is capable of binding to mRNA for several ion channels and is known to interact with ion channel-associated proteins (Brown et al., 2010; Darnell et al., 2011; Brager and Johnston, 2014). Although there is evidence for brain regionspecific alterations to channel function in FXS, (for review, see Contractor et al., 2015), it is unclear whether these effects are uniform across neuron types within a brain region. Here, we provide evidence for neuron-typespecific alterations to ion channel function within the prefrontal cortex (PFC) of fmr1-/y mouse.

Neuronal dysfunction in the fmr1-/y mouse can be attributed to differences in several types of ion channels (Meredith et al., 2007; Strumbos et al., 2010; Brager et al., 2012; Deng et al., 2013; Routh et al., 2013; Zhang et al., 2014). In some cases, reports are conflicting as to the effect of the loss of FMRP on a given type of ion channel. Some have reported an increase (Lee et al., 2011) in $\mathrm{Kv} 4 / \mathrm{A}$-type $\mathrm{K}^{+}$channel expression, whereas others have found a decrease (Gross et al., 2011; Routh et al., 2013). Similarly, h-channels have been reported to be upregulated in hippocampus (Brager et al., 2012), but downregulated in L5B neurons of somatosensory cortex (Zhang et al., 2014).

We tested the hypothesis that the absence of FMRP has different effects on the function of a single type of ion channel in PFC, a brain region containing a heterogeneous neuron population and that is implicated in behavioral deficits associated with FXS (Menon et al., 2004; Krueger et al., 2011; Wang et al., 2012; Dembrow and Johnston, 2014). Using current-clamp and outside-out patch-clamp recordings from fmr1-ly mice we provide evidence that $I_{\mathrm{h}}$ (the current mediated by h-channels) is down-regulated in pyramidal tract (PT)-projecting neurons. This is in contrast to hippocampal CA1 pyramidal neurons, but similar to L5 neurons in somatosensory cortex. Using outside-out patch-clamp recordings, we measured three distinct types of potassium currents: rapidly inactivating A-type current, mediated by putative Kv4 channels; a slowly inactivating current, mediated by putative Kv1 channels; and a sustained current. Again, in contrast to hippocampus, we find that the maximum putative Kv4-mediated current is increased in PT neurons. Additionally, the maximum putative Kv1-mediated current is decreased at the soma of PT neurons, resulting in increased excitability. Notably, these somatic $\mathrm{K}^{+}$channel differences do not extend to neighboring intra-

Correspondence should be addressed to Brian E. Kalmbach, Center for Learning and Memory, The University of Texas at Austin, 1 University Station, C7000, Austin, TX 78712. E-mail: brian@mail.clm.utexas.edu.

DOI:http://dx.doi.org/10.1523/ENEURO.0114-15.2015

Copyright (C) 2015 Kalmbach et al.

This is an open-access article distributed under the terms of the Creative Commons Attribution 4.0 International, which permits unrestricted use, distribution and reproduction in any medium provided that the original work is properly attributed. telencephalic-projecting (IT) neurons within L5. Thus, the absence of FMRP has divergent effects on a given type of ion channel in different cell types, even within a single brain region. These findings highlight the need to understand FXS and its treatment in a neuron type/brain regionspecific manner.

\section{Materials and Methods}

\section{Bead infusions}

All procedures involving animals were approved by the Institutional Animal Care and Use Committee. Male wildtype (WT; C57BL/6) and fmr1-/y mice were anesthetized with isoflurane ( $1-4 \%$ mixed in oxygen) and prepared for stereotaxic injection of retrograde transported fluorescent-labeled microspheres (Lumafluor). Beads $(100 \mathrm{nl})$ were injected into the pons (in millimeters relative to bregma: posterior 4.2; lateral 0.4 ; ventral 4.5), mPFC (anterior 1.0-1.5; lateral 0.45; ventral 1-2), or striatum (posterior 0.4-1.0; lateral 2.25; ventral 3.5), using a glass pipette $(\sim 15 \mu \mathrm{m}$ diameter tip) connected to a nanoject II auto-nanoliter injector (Drummond Scientific) at a rate of $23 \mathrm{nl} / \mathrm{s}$. For all injections, the pipette was left in place for 5 min before removing it from the brain. Mice were given analgesics (Carprofen; $5 \mathrm{mg} / \mathrm{kg}$ ) and recovered for at least $2 \mathrm{~d}$ before their use in experiments. Mice that received different colored beads to label IT and PT neurons were anesthetized with a ketamine $(100 \mathrm{mg} / \mathrm{kg}) / x y$ lazine $(10$ $\mathrm{mg} / \mathrm{kg}$ ) mixture and were perfused through the heart with ice-cold saline consisting of the following (in $\mathrm{mm}$ ): $2.5 \mathrm{KCl}$, $1.25 \mathrm{NaH}_{2} \mathrm{PO}_{4}, 25 \mathrm{NaHCO}_{3}, 0.5 \mathrm{CaCl}_{2}, 7 \mathrm{MgCl}_{2}, 7 \mathrm{dex}-$ trose, 205 sucrose, 1.3 ascorbate, and 3 sodium pyruvate (bubbled with $95 \% \mathrm{O}_{2} / 5 \% \mathrm{CO}_{2}$ to maintain $\mathrm{pH} \sim 7.4$ ) followed by $4 \%$ paraformaldehyde in $0.1 \mathrm{M}$ phosphate buffer. Three hundred-micrometer-thick coronal slices were visualized with a Zeiss Axio Imager Z2 microscope running Axio Vision software (Carl Zeiss). We looked for clear instances of overlap of green and red puncta across at least four $300 \mu \mathrm{m}$ sections per animal.

\section{Slice preparation}

Male WT and fmr1-/y mice, 8-16 weeks old, were anesthetized with a ketamine $(100 \mathrm{mg} / \mathrm{kg}) / x y l a z i n e ~(10$ $\mathrm{mg} / \mathrm{kg}$ ) mixture and were perfused through the heart with ice-cold saline consisting of the following (in $\mathrm{mm}$ ): $2.5 \mathrm{KCl}$, $1.25 \mathrm{NaH}_{2} \mathrm{PO}_{4}, 25 \mathrm{NaHCO}_{3}, 0.5 \mathrm{CaCl}_{2}, 7 \mathrm{MgCl}_{2}, 7 \mathrm{dex}-$ trose, 205 sucrose, 1.3 ascorbate, and 3 sodium pyruvate (bubbled with $95 \% \mathrm{O}_{2} / 5 \% \mathrm{CO}_{2}$ to maintain $\mathrm{pH} \sim 7.4$ ). $\mathrm{A}$ vibrating tissue slicer (Vibratome 3000, Vibratome) was used to make $300-\mu \mathrm{m}$-thick coronal sections. Slices were held for $30 \mathrm{~min}$ at $35^{\circ} \mathrm{C}$ in a chamber filled with artificial CSF (aCSF) consisting of the following (in $\mathrm{mm}$ ): $125 \mathrm{NaCl}$, $2.5 \mathrm{KCl}, 1.25 \mathrm{NaH}_{2} \mathrm{PO}_{4}, 25 \mathrm{NaHCO}_{3}, 2 \mathrm{CaCl}_{2}, 2 \mathrm{MgCl}_{2}, 10$ dextrose, and 3 sodium pyruvate (bubbled with 95\% $\mathrm{O}_{2} / 5 \% \mathrm{CO}_{2}$ ) and then at room temperature until the time of recording.

\section{Electrophysiology}

Recordings were made from L5 pyramidal neurons in the dorsal, medial prefrontal cortex $\sim 1-2 \mathrm{~mm}$ anterior to bregma. Slices were placed in a submerged, heated (32- 
$34^{\circ} \mathrm{C}$ ) recording chamber that was continually perfused $(1-2 \mathrm{ml} / \mathrm{min}$ ) with bubbled aCSF containing the following (in mM): $125 \mathrm{NaCl}, 3.0 \mathrm{KCl}, 1.25 \mathrm{NaH}_{2} \mathrm{PO}_{4}, 25$ $\mathrm{NaHCO}_{3}, 2 \mathrm{CaCl}_{2}, 1 \mathrm{MgCl}_{2}, 10$ dextrose, 3 sodium pyruvate, 0.025 D-APV, 0.02 DNQX, 0.005 CGP, and 0.002 gabazine. For outside-out recordings, $0.001 \mathrm{mM}$ TTX was added to the aCSF. Slices were viewed with either: (1) a Zeiss Axioskop microscope and differential interference optics, (2) a Zeiss AxioExaminer D microscope and Dodt contrast optics, or (3) a two-photon laser-scanning microscope (Leica SP5 RS) using Dodt contrast. Fluorescentlabeled neurons were visualized using a mercury lamp and a $540 / 605 \mathrm{~nm}$ or $470 / 502 \mathrm{~nm}$ excitation/emission filter set or two-photon excitation at $840 \mathrm{~nm}$. Patch pipettes (4-8 M 2 ) were pulled from borosilicate glass and wrapped with Parafilm to reduce capacitance. The pipette solution for all configurations contained the following (in $\mathrm{mm}$ ): $120 \mathrm{~K}$-gluconate, $16 \mathrm{KCl}, 10 \mathrm{HEPES}, 8 \mathrm{NaCl}, 7 \mathrm{~K}_{2}$ phosphocreatine, $0.3 \mathrm{Na}$-GTP, $4 \mathrm{Mg}$-ATP, pH 7.3 with $\mathrm{KOH}$. Neurobiotin (Vector Laboratories; $0.1 \%$ ) was also included for histologic processing. For all experiments involving dendritic recordings and some experiments involving somatic recordings, AlexaFluor $594(16 \mu \mathrm{M}$; Invitrogen) was also included in the internal recording solution to determine the recording location. All drugs were prepared from concentrated stock solutions in water and were obtained from Abcam Pharmaceutical or Tocris.

\section{Whole-cell recordings}

Data were acquired using a Dagan BVC-700 (Dagan) amplifier and custom data acquisition software written using lgor Pro (Wavemetrics) or AxoGraph X (AxoGraph Scientific) data acquisition software. Data were acquired at $10-50 \mathrm{kHz}$, filtered at $5-10 \mathrm{kHz}$, and digitized by an ITC-18 (InstruTech) interface. Pipette capacitance was compensated and the bridge was balanced during each recording. Series resistance was monitored throughout each experiment and was $10-25 \mathrm{M} \Omega$ for somatic recordings and $15-40 \mathrm{M} \Omega$ for dendritic recordings. Voltages are not corrected for the liquid-junction potential (estimated as $\sim 12 \mathrm{mV}$ ).

Data were analyzed using either custom analysis software written in Igor Pro or using AxoGraph X. Subthreshold membrane properties were measured at a common membrane potential $(-65 \mathrm{mV})$. Input resistance $\left(R_{\mathrm{N}}\right)$ sag and rebound were calculated from the voltage response to a family of $1000 \mathrm{~ms}$ current injections $(-150$ to $+50 \mathrm{pA}$, 20 pA steps. Input resistance $\left(R_{N}\right)$ was calculated from the linear portion of the current-voltage relationship. Voltage sag was defined as the ratio of maximum to steady-state $R_{\mathrm{N}}$. Rebound slope was calculated from the slope of the rebound amplitude as a function of steady-state membrane potential. The functional membrane time constant was defined as the slow component of a doubleexponential fit of the average voltage decay in response to hyperpolarizing current injections (100-300 pA, 2 ms). Resonance was determined from the voltage response to a constant amplitude sinusoidal current injection that linearly increased in frequency from $1-15 \mathrm{~Hz}$ in $15 \mathrm{~s}$. The impedance amplitude profile (ZAP) was constructed from the ratio of the fast Fourier transform of the voltage response to the fast Fourier transform of the current injection. The peak of the ZAP was defined as the resonant frequency. Single action potentials (APs) were elicited using just-threshold current injections of various durations. AP threshold was defined as the voltage where the first derivative first exceeded $20 \mathrm{mV} / \mathrm{ms}$. Simulated synaptic currents were generated with exponentially rising (dendrite $=0.2 \mathrm{~ms}$; soma $=0.3 \mathrm{~ms}$ ) and decaying (dendrite $=2 \mathrm{~ms}$; soma $=4 \mathrm{~ms}$ ) waveforms. The amplitude of this waveform was adjusted such that amplitude of the voltage response to a single simulated event was $\sim 3 \mathrm{mV}$. For recordings from non-labeled neurons, the presence $(>2.2 \mathrm{~Hz})$ or absence of resonance was used to classify neurons into projection types.

\section{Outside-out recordings}

Membrane currents were recorded using an Axopach 200B amplifier (Molecular Devices), sampled at $10 \mathrm{kHz}$, analog filtered at $2 \mathrm{kHz}$ and digitized by an ITC-18 interface connected to a computer running Axograph X. For $\mathrm{K}^{+}$channels, activation curves were constructed by using depolarizing voltage commands ( -70 to $50 \mathrm{mV}$ in $20 \mathrm{mV}$ steps) to activate $I_{\mathrm{K}}$ from a holding potential of $-90 \mathrm{mV}$. Activation data were fit to a single Boltzmann function using a least-squares program. For voltage commands more hyperpolarized than $-10 \mathrm{mV}$, we extrapolated the slow time constant of the current back to the time equal to the peak of the total current. In this way, the peak of the slow and fast inactivating currents could be separated. The accuracy of this procedure was confirmed using a small set of experiments where the slowly inactivating component was measured directly. Linear leakage and capacitive currents were digitally subtracted by scaling traces at smaller command voltages in which no voltagedependent current was activated.

\section{Data analysis}

Repeated-measures (RM) ANOVA, between-subject factors ANOVA, mixed factors ANOVA, and post hoc $t$ tests were used to test for statistical differences between experimental conditions. Bonferroni correction was used to correct for multiple comparisons. Pearson's product moment correlation was used to test for statistically significant correlations between variables. Error bars represent SEM. Statistical analyses were performed Prism (Graphpad). Data are presented in the text as mean \pm SEM.

\section{Results}

\section{The organization of L5 projection neurons is maintained in the fmr1-/y mouse PFC}

Testing for differences in ion channel function is complicated by heterogeneity in pyramidal neuron types within PFC. Pyramidal neurons are present throughout L2-6 and possess distinct morphology, connectivity, and repertoires of ion channels (Molyneaux et al., 2007; Shepherd, 2013; Dembrow and Johnston, 2014). For example, in L5, neurons projecting solely within the telencephalon (IT) possess distinct morphologic and physiologic prop- 
erties from those of neighboring neurons that project subcortically through the PT (Christophe et al., 2005; Molnár and Cheung, 2006; Hattox and Nelson, 2007; Dembrow et al., 2010; Morishima et al., 2011; Otsuka and Kawaguchi, 2011; Sheets et al., 2011; Avesar and Gulledge, 2012; Gee et al., 2012; Kalmbach et al., 2013; Lee et al., 2014).

Before testing for alterations to physiology, we first asked whether the two general types of L5 projection neurons are found in the fmr1-/y mouse medial PFC (mPFC). In WT and fmr1-/y mice, we infused red retrograde tracer (Lumuflour beads) into the pontine nuclei to label PT neurons and a green tracer into either the contralateral striatum or contralateral mPFC to label IT neurons. In both genotypes, IT neurons were found throughout L2-6, whereas PT neurons were restricted to L5/6. Within the deep layers, PT and IT neurons could be observed within close proximity to each other at all depths $(<20 \mu \mathrm{m})$. Furthermore, we did not observe clearly any double-labeled neurons in either genotype ( $n=2$ for each genotype; Fig. 1A). Together, these data suggest that in fmr1-/y mice, as in WT mice, IT and PT neurons represent two non-overlapping populations of neurons.

As an additional test, we next asked whether L5 IT and PT neurons in fmr1-/y mice could be distinguished based upon their physiologic properties. PT neurons possess conductances that endow them with membrane resonance in the 3-7 Hz range whereas IT neurons are nonresonant. Thus, the presence of resonance can be used to distinguish PT from IT neurons (Dembrow et al., 2010). For these experiments, we made whole-cell current-clamp recordings from the soma of identified L5 PT or IT neurons, as well as nearby unlabeled cells. In both WT ( $n=15$ cells from 6 mice, $4.11 \pm 0.32 \mathrm{~Hz})$ and fmr1-/y $(n=21$ cells from 7 mice, $2.79 \pm 0.19 \mathrm{~Hz}$ ) mice, PT neurons displayed membrane resonance whereas IT neurons did not (WT: $n=17$ cells from 5 mice, $1.07 \pm 0.06 \mathrm{~Hz}$; fmr1-/y: $n=19$ cells from 6 mice, $1.01 \pm 0.01 \mathrm{~Hz}$; IT vs PT, $p<0.001^{a}$, ANOVA; Fig. 1B,C; Table 1). Furthermore, in both genotypes, input resistance $\left(R_{N}\right)$ was significantly higher in PT compared with IT neurons (WT PT = 79.53 \pm $6.65 \mathrm{M} \Omega$; WT IT $=112.90 \pm 11.78 \mathrm{M} \Omega$; fmr1-/y PT $=$ $89.04 \pm 5.21 \mathrm{M} \Omega$, fmr1-/y IT $171.3 \pm 8.73 \mathrm{M} \Omega ; p<$ $0.001^{\mathrm{b}}$, ANOVA; Fig. $\left.1 B, C\right)$. We also recorded from nonresonant (WT: $n=3$ cells from 2 mice; fmr1-/y: $n=3$ from 2 mice) and resonant (WT: $n=13$ from 4 mice; fmr1-ly: $n$ $=11$ cells from 3 mice) non-labeled neurons with physiologic properties that closely resembled nearby labeled IT and PT neurons, respectively. When these putative IT and PT neurons were grouped with labeled projection neurons for analysis, we found that in both genotypes, PT neuron resonant frequency was inversely correlated with $R_{\mathrm{N}}$, whereas in IT neurons it was not (Fig. 1C; WT PT: $r^{2}=$ $0.22, p=0.01^{\mathrm{c}}$; WT IT: $r^{2}=0.01, p=0.62$; fmr1-/y PT: $r^{2}$ $=0.12, p=0.05$, fmr1-/y IT: $r^{2}=0.08, p=0.18$ ). These data are consistent with findings in rat MPFC (Dembrow et al., 2010) and suggest that the organization of projection neurons in L5 of PFC is maintained in the fmr1-/y mouse. For our purposes, unlabeled neurons that display resonance will be referred to as PT neurons, whereas those that do not will be referred to as IT neurons.

\section{$I_{\mathrm{h}}$ is reduced in L5 neurons in the fmr1-/y mouse mPFC}

The intrinsic membrane properties of pyramidal neurons are heavily influenced by the presence of voltage-gated ion channels (Magee, 2000; London and Häusser, 2005; Johnston and Narayanan, 2008). The expression of one class of channel, h-channels, which carry $I_{h}$, has been reported to be up-regulated in CA1 but down-regulated in somatosensory cortex in the fmr1-/y mouse (Brager et al., 2012; Zhang et al., 2014).

To test for alterations to h-channel function in PFC we measured $I_{\mathrm{h}}$-sensitive membrane properties (membrane potential $-V_{m}, R_{N}$, time constant - tau, sag, rebound, resonance, and temporal summation; Hutcheon and Yarom, 2000; Robinson and Siegelbaum, 2003; Brager and Johnston, 2007; Narayanan and Johnston, 2007) in WT and fmr1-/y neurons. Because h-channel expression in many types of cortical pyramidal neurons increases with distance from the soma (Lörincz et al., 2002; Kole et al., 2006), we performed these measurements at the soma (WT: $n=30$ cells from 18 mice; fmr1-/y: $n=35$ cells; from 17 mice), proximal dendrite ( $\leq 250 \mu \mathrm{m}$; WT: $n$ $=12$ cells from 9 mice; fmr1-/y: $n=17$ cells from 17 mice), and distal dendrite ( $>250 \mu \mathrm{m} ; \mathrm{WT}: n=34$ cells from 26 mice; fmr1-ly: $n=23$ cells from 17 mice). We focused our initial efforts on PT neurons because they have more pronounced h-channel associated properties (Fig. 1; Dembrow et al., 2010; Sheets et al., 2011; Kalmbach et al., 2013). $R_{N}$ was higher at proximal and distal dendritic recording locations $\left(p<0.01^{d}\right)$ in fmr1-ly compared with WT neurons, but this difference was not observed at the soma ( $p=0.21$; Fig. $2 A, B)$. Fmr1-/y neurons were more hyperpolarized, displayed less sag and less rebound than WT neurons, at all recording locations (all $p<0.01$; Fig. $2 A, B^{\mathrm{e}}$ ). Furthermore, the resonant frequency of fmr1-ly neurons was lower and the functional membrane time constant longer than WT neurons at all recording locations $\left(p<0.01\right.$; Fig. $\left.2 C, D^{f}\right)$. Finally, fmr1-/y neurons displayed greater temporal summation of simulated synaptic currents at both the soma and distal dendritic recording locations $(p<0.001$, ANOVA; Fig. $2 E^{g}$ ). Together, these differences in membrane properties between genotypes suggest that there is a decrease in $I_{\mathrm{h}}$ at both the soma and dendrite of L5 PT neurons in PFC of fmr1-ly mice.

To test for differences in IT neurons, we made many of these same measurements at the soma (WT: $n=20$ cells from 8 mice; fmr1-/y: $n=22$ cells from 10 mice) and dendrite (WT: $n=7$ cells from 7 mice; 125-270 $\mu \mathrm{m}$, $192.86 \pm 17.52 \mu \mathrm{m}$ from soma; fmr1-/y: $n=8$ cells from 8 mice; $145-300 \mu \mathrm{m}, 235 \pm 20.28 \mu \mathrm{m}$ from soma). In contrast to PT neurons, the subthreshold properties of IT neurons were largely similar in WT and fmr1-/y mice (all comparisons $p>0.1$; ANOVA; Fig. $3^{\mathrm{h}}$ ). The lone exception was resting membrane potential (RMP) where fmr1-/y neurons were more hyperpolarized compared with WT neurons $\left(p=0.02\right.$; ANOVA; Fig. $\left.3 A^{i}\right)$. Differences in RMP 
A

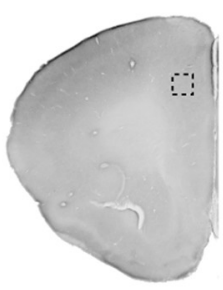

WT

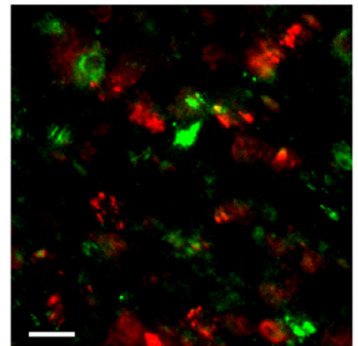

fmr1-/y

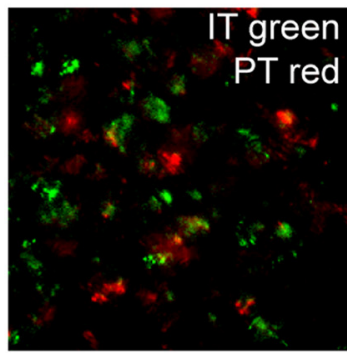

B

WT

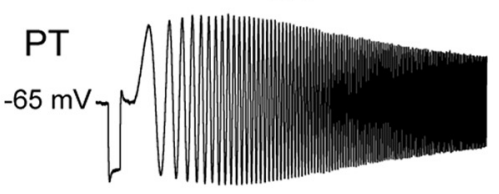

IT

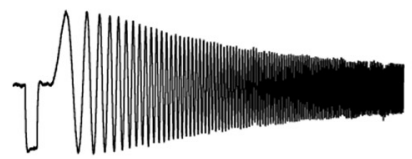

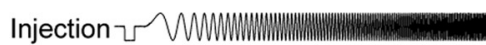

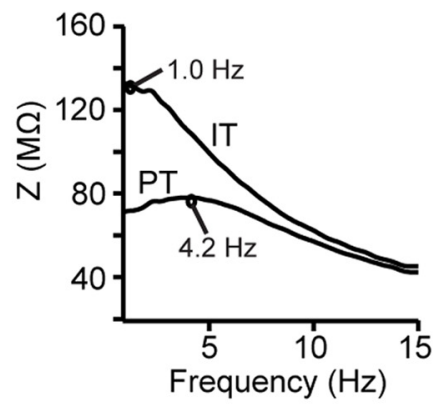

C

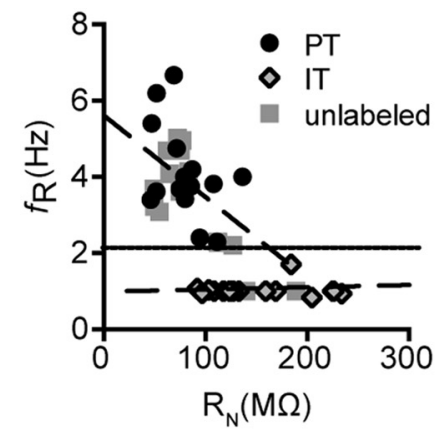

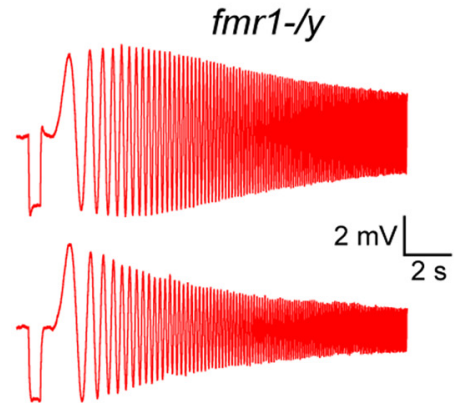
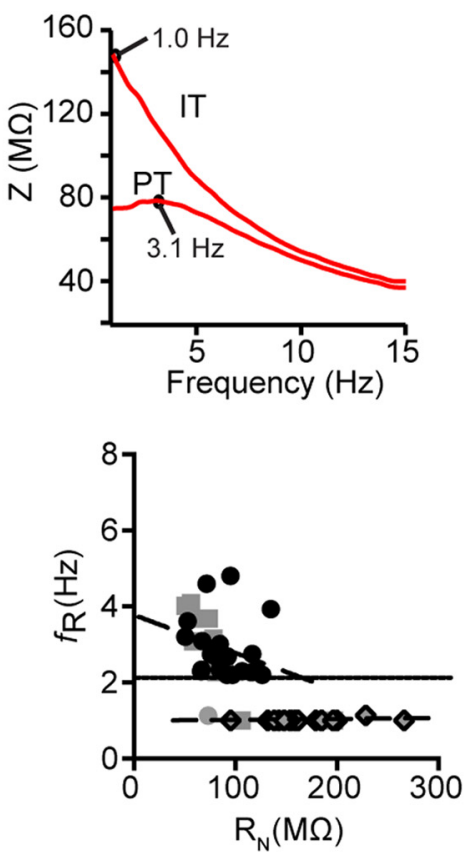

Figure 1. PT and IT neurons in L5 of mPFC in the fmr1-/y mouse. A, Coronal section of one hemisphere of mouse mPFC illustrating approximately where neurons where visualized. Retrograde labeled IT and PT neurons in the middle of L5 in WT (left) and fmr1-/y mouse mPFC. IT (green) and PT (red) neurons were non-overlapping populations of neurons in both genotypes. Scale bar, $20 \mu \mathrm{m}$. B. Response to a chirp current injection in WT (left) and fmr1-/y (right) PT and IT neurons and the resultant ZAP for each neuron. C, IT and PT neurons were distinguishable based on intrinsic membrane properties in both genotypes. In both genotypes, PT neurons were resonant, whereas IT neurons were non-resonant. $f_{\mathrm{R}}$ in PT neurons was negatively correlated with $R_{\mathrm{N}}$ in both genotypes $(p<0.05)$.

at the soma persisted in the presence of the h-channel blocker ZD7288 (10 $\mu \mathrm{M}$; WT: $n=6$ cells from 4 mice baseline $-64.33 \pm 1.50$ ZD7288 $-68.52 \pm 0.23 ;$ fmr1-ly: $n=6$ cells from 4 mice baseline $-69.63 \pm 1.56$ ZD7288
$-72.15 \pm 1.48 ; p=0.04 ;$ ANOVAj), suggesting that h-channels were not the main source of these differences.

To test whether the observed differences in PT neurons were due primarily to h-channels, we compared the ef- 
Table 1. Statistical Tests

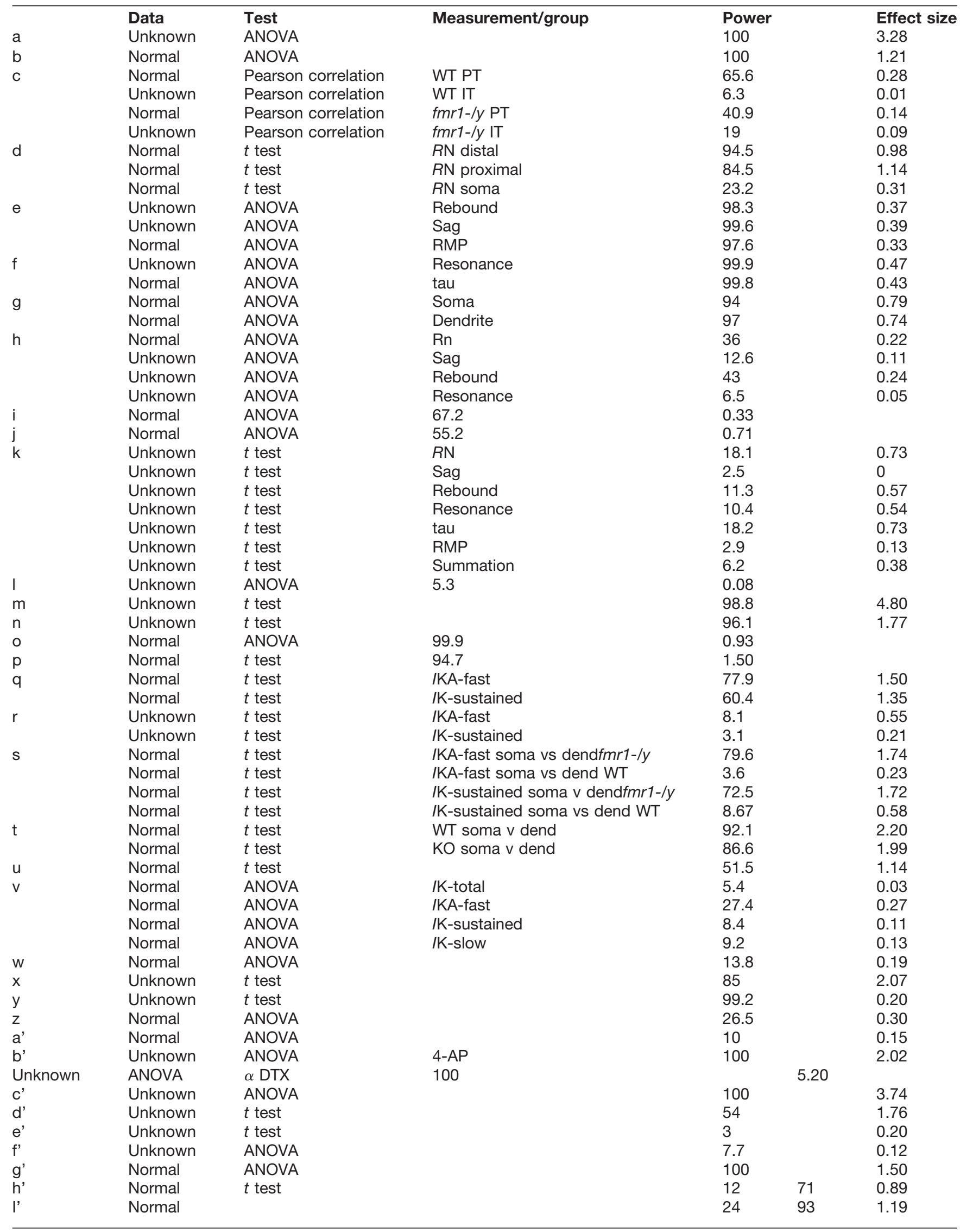




\begin{tabular}{|c|c|c|c|c|c|c|}
\hline & Data & Test & Measurement/group & Power & & Effect size \\
\hline j' & Normal & & & 50 & 88.9 & 1.11 \\
\hline \multirow{2}{*}{ 'k' } & Normal & & & 100 & & 0.51 \\
\hline & Normal & ANOVA & & 62.6 & & 0.21 \\
\hline k' & Normal & ANOVA & WT & 99.9 & & 0.90 \\
\hline l' & Normal & & fmr1-/y & 94.3 & & 0.61 \\
\hline n' & Normal & ANOVA & WT & 10 & & 0.14 \\
\hline $0^{\prime}$ & Normal & ANOVA & fmr1-/y & 17.78 & & 0.19 \\
\hline$p^{\prime}$ & Normal & ANOVA & & 99.9 & & 1.03 \\
\hline$q^{\prime}$ & Normal & ANOVA & & 92.2 & & 0.38 \\
\hline
\end{tabular}

Data structure was tested for normality using Kolmogorov-Smirnoff tests. In cases where the test for normality failed, nonparametric statistic yielded similar results. For some comparisons, the measurement and/or group under comparison is listed for clarity. Post hoc power analysis was performed using $\mathrm{G} \times$ Power (v3.1.9.2, www.Gpower.hhu.de).

fects of the ZD7288 on the properties of PT L5 dendrites in WT versus fmr1-/y mice. Application of $10 \mu \mathrm{M}$ ZD7288 largely eliminated the differences in membrane properties between WT ( $n=7$ cells from 6 mice) and fmr1-/y $(n=9$ cells from 7 mice) neurons measured at a common membrane potential ( $-65 \mathrm{mV}$; Fig. 4). There were no statistical differences in $R_{N}(p=0.12), V_{m}(p=0.94)$, sag $(p=0.40)$, rebound $(p=0.08$; Fig. $4 A, B)$, resonant frequency $(p=$ 0.37 ; Fig. $4 C$ ), tau ( $p=0.18$; Fig. $4 D$ ), or temporal summation of simulated synaptic input $(p=0.30$; Fig. $4 E)$ in the presence of ZD7288 in WT versus fmr1-/y neurons (all post hoc comparisons ${ }^{\mathrm{k}}$ ).

Finally, we made outside-out patch-clamp recordings from the distal dendrite of PT neurons to directly compare $I_{\mathrm{h}}$ in WT $(n=4$ cells from 3 mice; $225-400 \mu \mathrm{m}, 340 \pm 37.6$ $\mu \mathrm{m}$ from soma) and fmr1-/y ( $n=5$ cells from 5 mice; $250-350,308 \pm 17.7 \mu \mathrm{m}$ from soma) mice. Voltage steps from a holding potential of -30 to $-140 \mathrm{mV}$ elicited an inward current in both genotypes (Fig. 5A). The activation of this current was well fit by a double-exponential. The
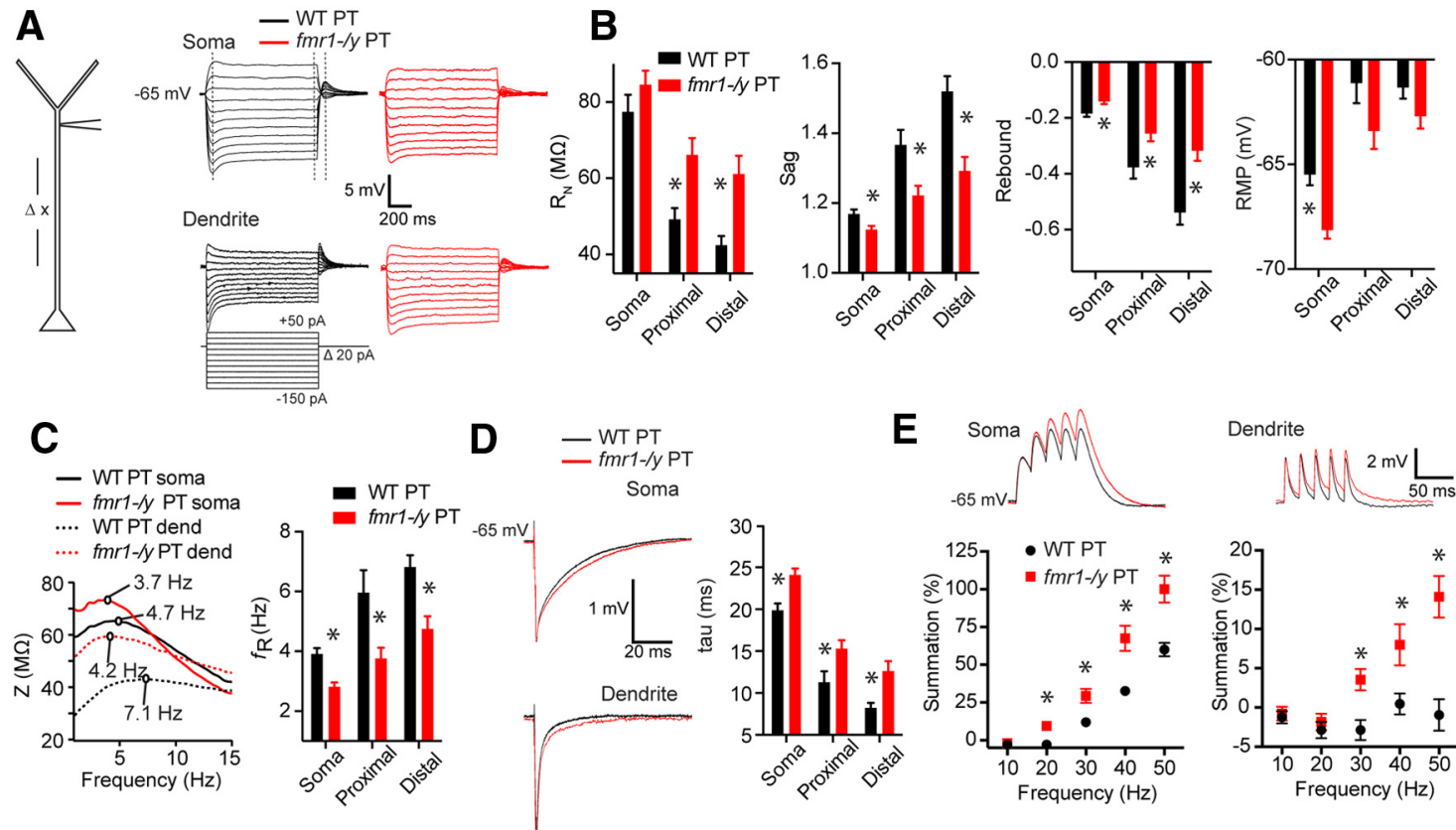

Figure 2. Altered h-dependent membrane properties in L5 PT neurons of mPFC in the fmr1-/y mouse. A, Left, Whole-cell recordings were made at various distances from the soma in WT and fmr1-/y mouse PT neurons. Right, Example traces from whole-cell recordings from the soma and dendrite of WT and fmr1-/y neurons in response to the current injection shown below. All recordings were made at $-65 \mathrm{mV} \boldsymbol{B}, R_{\mathrm{N}}$ was higher in the dendrite, but not soma of fmr1-/y neurons compared with WT. In addition, fmr1-/y neurons were more hyperpolarized and displayed less sag and rebound at the soma and dendrite compared with WT neurons. C, fmr1-/y neurons displayed a lower resonant frequency at the soma and dendrite compared with WT neurons. Sample ZAPs are shown at right. $\boldsymbol{D}$, The functional membrane time constant was longer in fmr1-/y compared with WT neurons, at all recording sites. $\boldsymbol{E}$, fmr1-/y neurons displayed greater temporal summation of simulated synaptic currents compared with WT neurons at the soma and distal dendritic recording locations. $* p<0.01$, post hoc comparison across genotypes. 

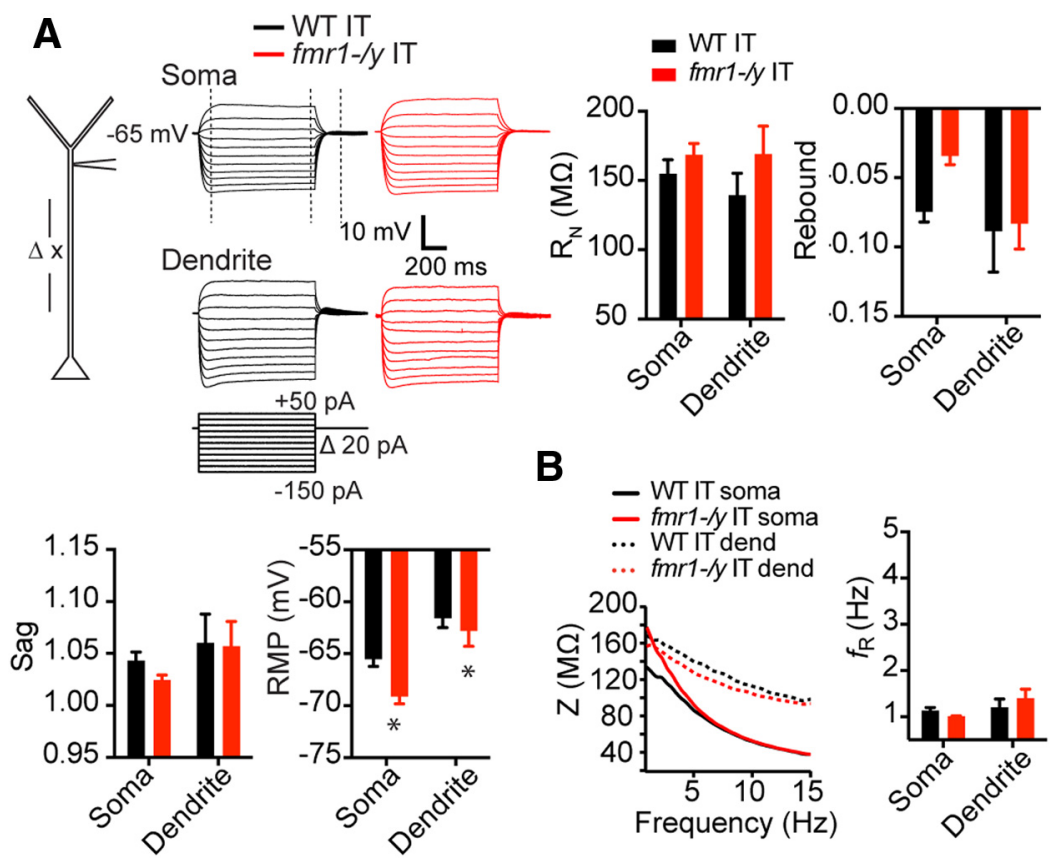

Figure 3. Subthreshold membrane properties are largely unaltered in IT neurons of PFC in the fmr1-/y mouse. A, Left, Whole-cell recordings were made at various distances from the soma in WT and fmr1-/y mouse IT neurons. Right, Example traces from whole-cell recordings from the soma and dendrite of WT and fmr1-/y neurons in response to the current injection shown below. All recordings were made at $-65 \mathrm{mV}$. $R_{\mathrm{N}}$, sag, and rebound were not different at the soma or dendrite in fmr1-/y compared with WT IT neurons. RMP was hyperpolarized in fmr1-/y compared with WT IT neurons. B, fmr1-/y and WT IT neurons both displayed a similar resonant frequency at the soma and dendrite. $* p<0.05$, post hoc comparison across genotypes.

fast and slow time constants were not different between genotypes and both were consistent with $I_{\mathrm{h}}$ (Fig. $5 B ; p=$ 0.87, mixed-ANOVA'; Dougherty et al., 2013). The maximum dendritic $I_{\mathrm{h}}$ was greater in WT compared with fmr1-/y neurons (Fig. 5C; $p=0.001, t$ test $^{\mathrm{m}}$ ). Finally, the resonant frequency measured during whole-cell before obtaining the outside-out configuration was lower in fmr1-/y compared with WT dendrites (Fig. $5 D ; p=0.03, t$ test $\left.^{\mathrm{n}}\right)$. These data are consistent with a decrease in the functional expression of h-channels in L5 PT neurons of PFC in the fmr1-ly mouse.

\section{Alterations to $I_{K}$ in L5 mPFC pyramidal neurons in fmr1-/y mice}

The observed decrease in $I_{\mathrm{h}}$ in PT neurons is in contrast to pyramidal neurons in CA1 of the hippocampus (Brager et al., 2012), but is similar to L5 pyramidal neurons in somatosensory cortex (Zhang et al, 2014). Together, these observations suggest that the absence of FMRP can have divergent effects on channel expression/function depending upon brain region or neuron type. A-type $\mathrm{K}^{+}$and $\mathrm{h}$-channel function are affected in opposite directions by several manipulations (Harris-Warrick et al., 1995; Bernard et al., 2004; Frick et al., 2004; Fan et al., 2005; Shin et al., 2008). Thus, we next asked whether the functional expression of A-type $\mathrm{K}^{+}$channels, which is decreased in CA1 pyramidal neurons in the fmr1-/y mouse (Routh et al., 2013), is increased in L5 neurons of mPFC and if so, whether the change is restricted to one class of L5 projection neuron.
We used outside-out patch recordings to measure the total $\mathrm{K}^{+}$current at the soma and distal dendrite $(\geq 250$ $\mu \mathrm{m}$ ) of PT L5 neurons in WT and fmr1-/y mice (Fig. 6A). The current elicited by step depolarization to $50 \mathrm{mV}$ from a holding potential of $-90 \mathrm{mV}$ contained both a transient and a sustained component ( $I_{\mathrm{K} \text {-total }}$; Fig. 6A1). Macroscopic $\mathrm{K}^{+}$currents in L5 neurons in granular cortex are composed of distinct channels with fast and slow inactivation kinetics (Bekkers, 2000; Korngreen and Sakmann, 2000). To test whether PT neurons in mPFC possess similar diversity in $\mathrm{K}^{+}$currents, we used the voltagedependent properties of the putative channels underlying each of these components to isolate the individual currents. A brief (100 ms) prepulse to $-20 \mathrm{mV}$ was used to inactivate the fast-inactivating current without significantly affecting either the sustained or slowly inactivating current (Fig. 6A2). Subtracting the resulting current from total $I_{\mathrm{K}}$ revealed a rapidly inactivating $\mathrm{K}^{+}$current $\left(I_{\mathrm{KA} \text {-fast }}\right.$; Fig. 6A4). Step depolarization to $50 \mathrm{mV}$ from a holding potential of $-20 \mathrm{mV}$, to inactivate all transient $\mathrm{K}^{+}$cur-

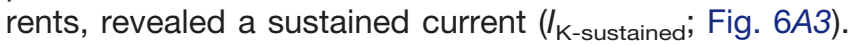
Subtracting $I_{K \text {-sustained }}$ from the current in Fig. $6 A 2$ revealed a slowly inactivating $\mathrm{K}^{+}$current $\left(I_{\mathrm{K} \text {-slow }}\right.$, Fig. $\left.6 A 5\right)$. Thus, we were able to isolate three kinetically distinct outward currents: $I_{\text {K-sustained }}, I_{\text {KA-fast }}$, and $I_{\text {K-slow }}$ (Fig. $6 A$ ).

The maximum $I_{K \text {-total }}$ was greater at the soma compared with the dendrite for WT and fmr1-/y neurons $\left(p<0.001^{\circ}\right.$, ANOVA). However, the maximum somatic $I_{\text {K-total }}$ in $f m r 1-/ y$ neurons was larger than that in WT neurons $(p=0.01$; Fig. $\left.6 B^{\mathrm{P}}\right)$. This difference in somatic $I_{\mathrm{K} \text {-total }}$ is due, in part, to 

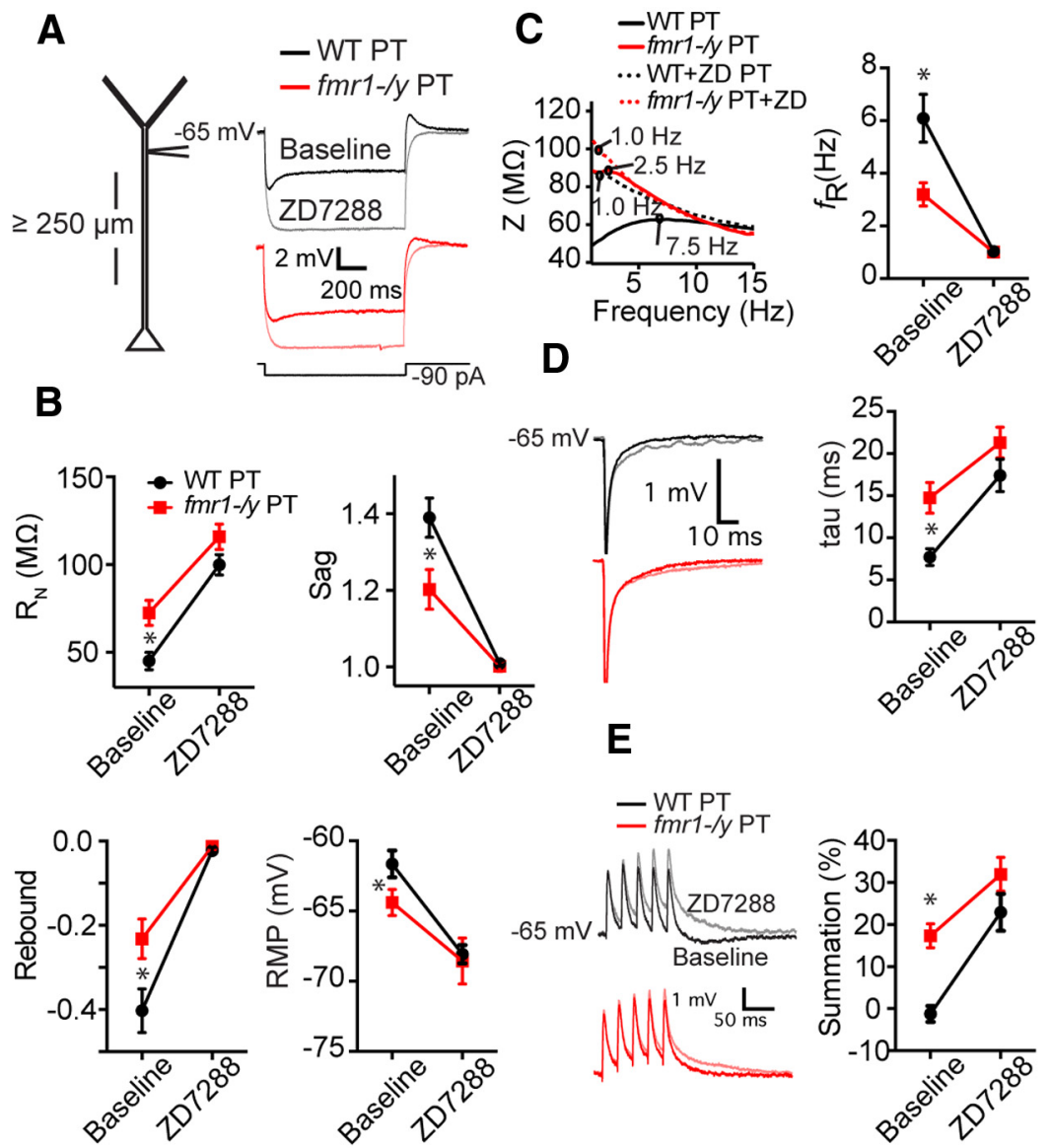

$E$
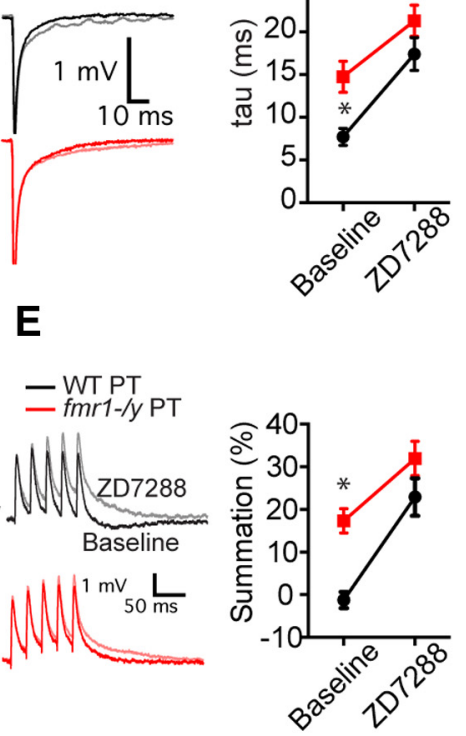

Figure 4. Differences in membrane properties between WT and fmr1-/y neurons are eliminated by the $h-c h a n n e l$ blocker, ZD7288. A, Sample voltage responses to a hyperpolarizing current injection at the distal dendrite of fmr1-/y and WT PT neurons. $\boldsymbol{B}$, ZD7288 (10 $\mu \mathrm{M})$ eliminated differences in $R_{\mathrm{N}}$, Sag, rebound and RMP between WT and fmr1-/y dendrites. C, ZD7288 also eliminated membrane resonance in both genotypes. $\boldsymbol{D}$, The functional membrane time constant and temporal summation of simulated synaptic currents delivered at $50 \mathrm{~Hz}(\boldsymbol{E})$ was no different between fmr1-/y and WT dendrites in the presence of ZD7288. All measurements were performed at $-65 \mathrm{mV}$. $* p<0.01$.

differences in both $I_{\mathrm{KA} \text {-fast }}$ and $I_{\mathrm{K} \text {-sustained. We observed }}$ larger $I_{\text {KA-fast }}$ and $I_{\mathrm{K} \text {-sustained }}$ at the soma $(p=0.05$; fast, $p$ $=0.05^{9}$ ) but not dendrite (sustained, $p=0.74$; fast, $p=$ 0.52 ), of fmr1-/y compared with WT neurons (Fig. 6C,E). Consequently, $I_{\text {KA-fast }}(p<0.01)$ and $I_{\text {K-sustained }}(p<0.05)$ were larger at the soma compared with the dendrite in fmr1-/y, but not WT neurons (Fig. 6C, $E^{\mathrm{s}}$ ). Interestingly, we also observed genotypic differences for the $I_{\mathrm{K} \text {-slow }} I_{\mathrm{K} \text {-slow }}$ was smaller at the dendrite compared with the soma in both genotypes $\left(p<0.05^{t}\right)$. In contrast to the other currents however, $I_{\mathrm{K} \text {-slow }}$ was smaller at the soma of fmr1-/y compared with WT neurons $\left(p<0.05\right.$; Fig. $\left.6 D^{\mathrm{u}}\right)$. In summary, at the soma of fmr1-/y PT neurons, there is a relative increase in the contribution of $I_{\text {KA-fast }}(57 \pm 3 \%$ vs $44 \pm 7 \%)$ and decrease in the contribution of $I_{\mathrm{K} \text {-slow }}(50 \pm$ $6 \%$ vs $36 \pm 3 \%$ ) to the somatic $I_{\mathrm{K} \text {-total }}$ compared with WT (Fig. 6F). In contrast, we observed no differences between genotypes in relative contribution of the three $\mathrm{K}^{+}$current components in the dendrites (Fig. 6G).

Relatively little is known about differences in $\mathrm{K}^{+}$channel expression at the soma of different projection neurons in L5. Therefore, we also made outside-out patch record- ings from IT neurons in MPFC to test whether the change in magnitude and relative contribution of $\mathrm{K}^{+}$currents observed at the soma of PT neurons is common to all pyramidal neurons within a brain region. Similar to PT neurons, the current elicited by step depolarization to 50 $\mathrm{mV}$ from a holding potential of $-90 \mathrm{mV}$ contained both transient and sustained components. In contrast to PT neurons however, we did not observe differences in any $I_{\mathrm{K}}$ component between fmr1-/y and WT IT neurons at the soma or dendrite (Fig. $7 ; p>0.05$, all comparisons ${ }^{v}$ ). Thus, in the fmr1-/y mouse, the maximum amplitude of $\mathrm{K}^{+}$ currents at the soma is affected in one type of projection neuron (PT), but not a neighboring type (IT). These data suggest that channel phenotypes in the fmr1-/y mouse can vary not only between brain regions (ie, hippocampus, somatosensory cortex and mPFC), but also within a brain region in different classes of principal neurons (PT vs IT).

A-type $\mathrm{K}^{+}$channels can be composed of either $\mathrm{Kv} 4$ or Kv1 subunits (Coetzee et al., 1999). To identify the putative channels underlying $I_{\mathrm{KA} \text {-fast }}$ and $I_{\mathrm{K} \text {-slow, we used two }}$ complementary approaches. First, we exploited differ- 

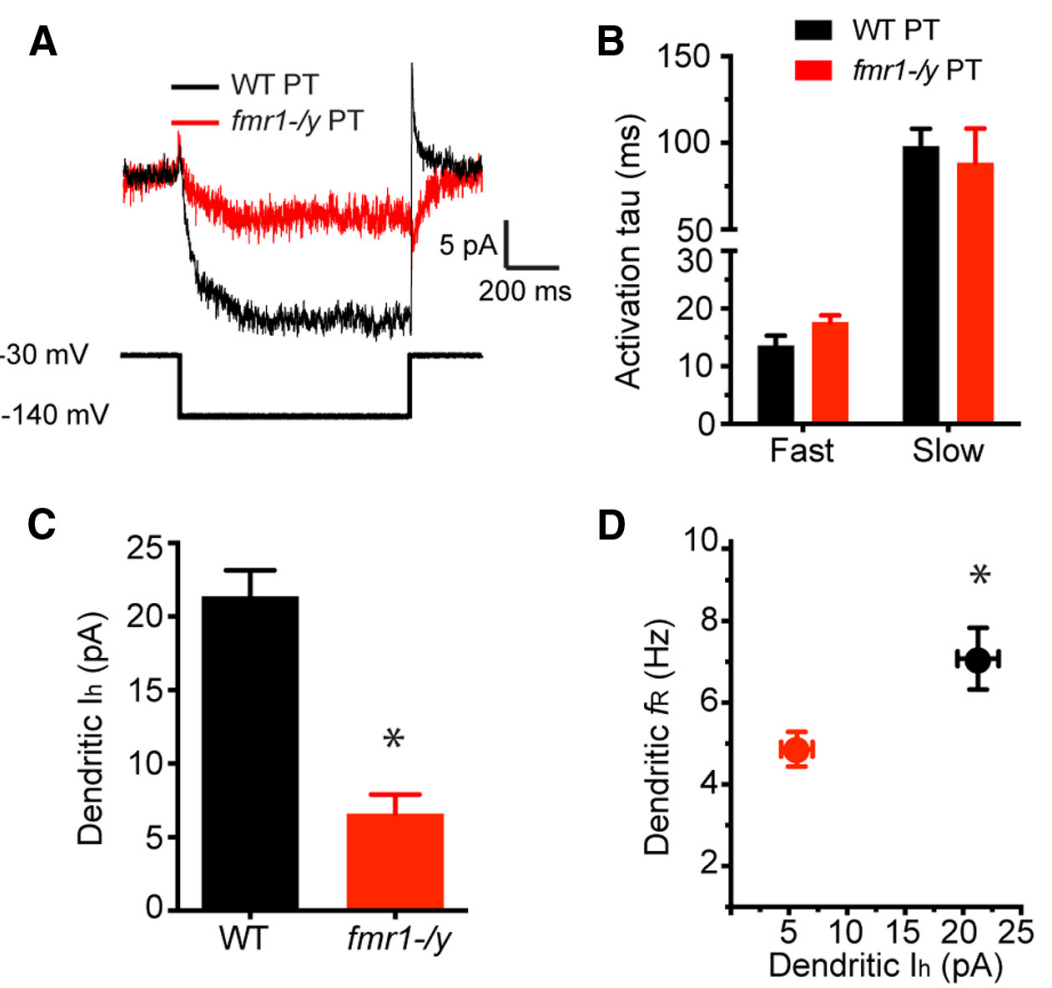

Figure 5. $I_{\mathrm{h}}$ is reduced in the dendrites of L5 PT neurons of PFC in the fmr1-/y mouse. A, h-Current was measured by stepping from a holding potential of $-30 \mathrm{mV}$ to $-140 \mathrm{mV}$ for $500 \mathrm{~ms}$. $\boldsymbol{B}$, There were no genotypic differences in the time constant of activation of $I_{\mathrm{h}}$. C, Both $I_{\mathrm{h}}$ and resonance $(\boldsymbol{D})$ were significantly reduced in the dendrite of $f m r 1-/ y$ neurons compared with WT. $* p<0.05$

ences in the kinetic properties of these channels. Kv1 containing channels tend to inactivate and recover from inactivation an order of a magnitude slower than Kv4 containing channels (Castellino et al., 1995; Jerng et al., 2004). The time constant of inactivation $\left(\tau_{\text {inactivation }}\right)$ of the $I_{\text {KA-fast }}$ was not different between WT and fmr1-/y for either PT (WT $\tau_{\text {inactivation }}=29 \mathrm{~ms}$; fmr1-/y $\tau_{\text {inactivation }}=25$ $\mathrm{ms}$ ) or IT neurons (WT $\tau_{\text {inactivation }}=28 \mathrm{~ms}$; fmr1-/y $\tau_{\text {inactivation }}=23 \mathrm{~ms} ; p=0.88$, ANOVA $\left.{ }^{\mathrm{w}}\right)$. These values were consistent with $\mathrm{Kv} 4$ channels. The $\tau_{\text {inactivation }}$ of the $I_{\mathrm{K} \text {-slow }}$ was an order of magnitude larger than the $\tau_{\text {inactivation }}$ of the $I_{\text {KA-fast }}$ in both WT and fmr1-/y for PT and IT neurons, consistent with $\mathrm{Kv} 1$ channels. A closer comparison revealed that the $\tau_{\text {inactivation }}$ of the $I_{\mathrm{K} \text {-slow }}$ in fmr1-/y PT neurons was significantly smaller compared with WT PT neurons (WT $\tau_{\text {inactivation }}=646 \pm 95 \mathrm{~ms}$; fmr1-/y $\tau_{\text {inactivation }}$ $\left.=244 \pm 44 \mathrm{~ms} ; p=0.01^{\times}\right)$. By contrast, there was no statistically significant difference in $\tau_{\text {inactivation }}$ for $I_{\mathrm{K} \text {-slow }}$ in IT neurons (WT $\tau_{\text {inactivation }}=630 \pm 100 \mathrm{~ms}$; fmr1-/y $\tau_{\text {inactivation }}=425 \pm 69 \mathrm{~ms} ; p>0.05$, Fig. $\left.8 A^{y}\right)$. Next, we used a two-pulse protocol to measure the recovery from inactivation. We found that the time course of recovery from inactivation was well fit by two exponentials consistent with two types of transient $\mathrm{K}^{+}$channels. Both the fast $\left(p=0.2\right.$, ANOVA $\left.^{z}\right)$ and slow $\left(p=0.5\right.$, ANOVA $\left.{ }^{a^{\prime}}\right)$ time constant of recovery from inactivation were similar in WT and fmr1-/y for L5 PT and IT neurons and were consistent with Kv4-containing and Kv1-containing channels, respectively (Fig. 8B-D).
As an additional method of identifying the channels underlying these currents, we exploited differences in the sensitivity of $\mathrm{Kv} 1$ and $\mathrm{Kv} 4$ containing channels to $\mathrm{K}^{+}$channel blockers. Specifically, we measured the sensitivity of macroscopic $\mathrm{K}^{+}$currents to $50 \mu \mathrm{M}$ 4-aminopyridine (4-AP) and $150 \mu \mathrm{M} \mathrm{Ba}^{2+}$, which preferentially block $\mathrm{K}_{\mathrm{v}} 1$-containing and $\mathrm{K}_{\mathrm{v}} 4$-containing channels, respectively (Castle et al., 1994; Russell et al., 1994; Stephens et al., 1994; Coetzee et al., 1999; Gasparini et al., 2007). Additionally, we measured the sensitivity of these currents to alpha-dendrotoxin $(\alpha-$ DTX), which preferentially blocks Kv1.1-, 1.2-, and 1.6containing channels (Harvey, 2001). 4-AP $(50 \mu \mathrm{M})$ and $\alpha$-DTX (200 nM) decreased $I_{\text {KA- slow }}$ without significantly affecting $I_{\text {KA-fast }}(p<0.01, n=8$ patches from 4 mice and $p<0.001, n=5$ patches from 4 mice, respectively; two-way RM ANOVA; Fig. 9A, $\left.B^{\mathrm{b}^{\prime}}\right)$. In contrast, $150 \mu \mathrm{M}$ $\mathrm{Ba}^{2+}$ decreased $I_{K A}$-fast without significantly affecting $I_{\text {KA-slow }}(p<0.005, n=5$ patches from 3 mice; two-way RM ANOVA; Fig. $9 C^{c^{\prime}}$ ). Furthermore, the amplitude of the DTX- and 4-AP-sensitive current was similar to the amplitude of $I_{\text {KA-slow, }}$ whereas the amplitude of the $\mathrm{Ba}^{2+}$-sensitive current was similar to the amplitude of $I_{\text {KA-fast }}$ (Fig. 9D). Together, these data suggest that Kv4 containing channels contribute to $I_{\mathrm{KA} \text {-fast }}$ and Kv1 con-

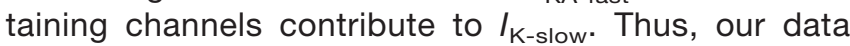
suggest that in the fmr1-/y mouse, there are alterations to the functional expression of two $\mathrm{K}^{+}$channels in PT L5 neurons of mPFC; there is an increase in the expres- 
A

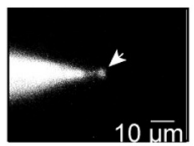

A2

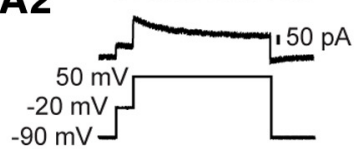

A4

Ik

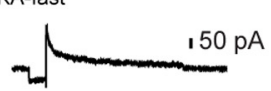

A1

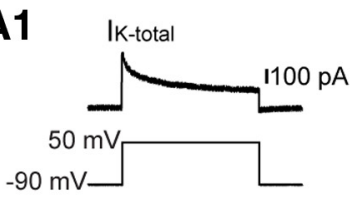

A3

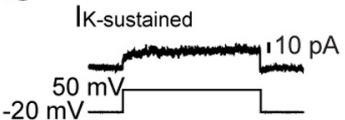

A5

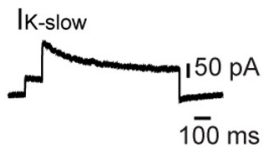

B

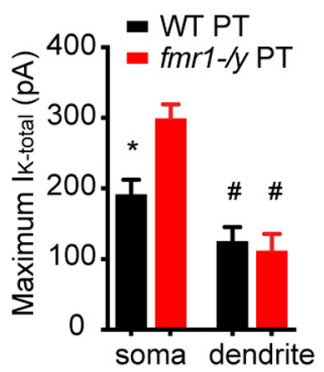

E

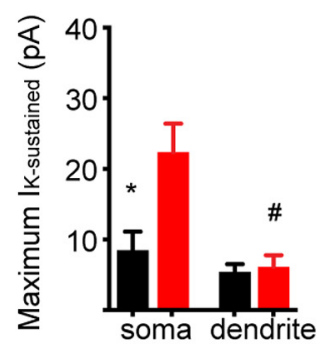

C

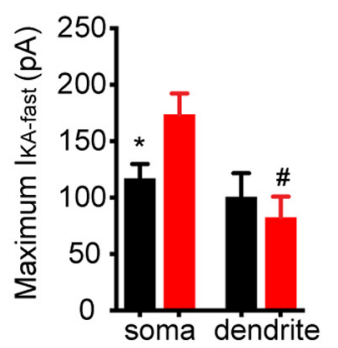

F

Soma

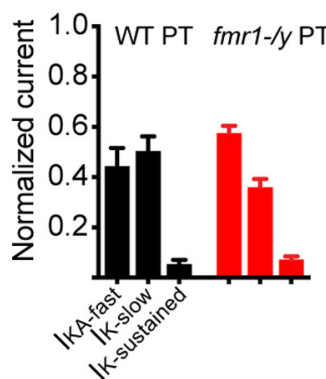

D

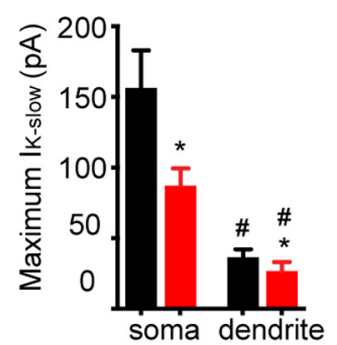

G

Dendrite

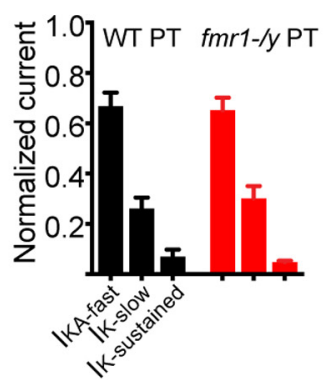

Figure 6. Differences in $I_{\mathbf{K}}$ in PT neurons in fmr1-/y versus WT mice. A, Outside-out patch from a PT neuron visualized through fluorescence microscopy. $I_{\mathrm{K} \text {-total }}$ was measured by stepping to $+50 \mathrm{mV}$ from a holding potential of $-90 \mathrm{mV}$. A prepulse to $-20 \mathrm{mV}$ was used to inactivate fast inactivating $I_{\mathrm{KA}} \cdot I_{\mathrm{K} \text {-sustained }}$ was obtained by stepping from a holding potential of $-20 \mathrm{mV}$ to $+50 \mathrm{mV}$. $I_{\mathrm{KA} \text {-fast }}$

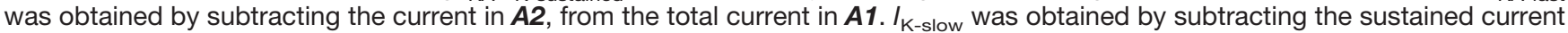
in $\boldsymbol{A} 3$ from the current obtained in A2. B. Maximum $I_{\mathrm{K} \text {-total }}$ at the soma is greater in fmr1-/y PT neurons compared with WT neurons. $\boldsymbol{C}$, Maximum $I_{\mathrm{KA} \text {-fast }}$ at the soma is greater in fmr1-/y neurons compared with WT. $\boldsymbol{D}$, Maximum $I_{\mathrm{K} \text {-slow }}$ at the soma of $f m r 1 / y$ neurons is less compared with WT neurons. $\boldsymbol{E}$, At the soma, maximum $I_{\mathrm{K} \text {-sustained }}$ is greater in fmr1-/y PT neurons compared with WT. $\boldsymbol{F}$, Summary of somatic differences in $I_{\mathrm{K}}$ between WT and fmr1-/y neurons. G, There were no differences in dendritic $\mathrm{K}^{+}$currents in fmr1-/y compared with WT neurons.

sion of Kv4-containing channels and a decrease in Kv1-containing channels.

In addition to a decrease in channel expression, there is a hyperpolarizing shift in the voltage dependence of activation of Kv4 channels in CA1 pyramidal neuron dendrites of fmr1-/y mice (Routh et al., 2013). Thus, although there is a decrease in total maximum current, there are relatively more channels open at hyperpolarized potentials in fmr1-/y mice compared with WT mice. To test for similar alterations to channel function in $\mathrm{L} 5$ neurons of $\mathrm{mPFC}$, we measured the voltage dependence of activation of fast A-type $\mathrm{K}^{+}$channels in somatic and dendritic patches from WT and fmr1-/y mice (Fig. 8E). Consistent with published reports in granular cortex (Bekkers, 2000), there was a hyperpolarizing shift in the activation curve of $I_{\text {KA-fast }}$ at the dendrite compared with the soma in WT L5 PT neurons ( $p$ $=0.03$; Fig. $\left.8 F, H^{d^{\prime}}\right)$. In contrast, there was no such shift in fmr1-/y neurons $\left(p=0.76\right.$; Fig. $\left.8 G, H^{e^{\prime}}\right)$. Furthermore, there was no difference in slope factor between WT and fmr1-ly neurons at either recording location $\left(p>0.3^{f^{\prime}}\right.$, 
A

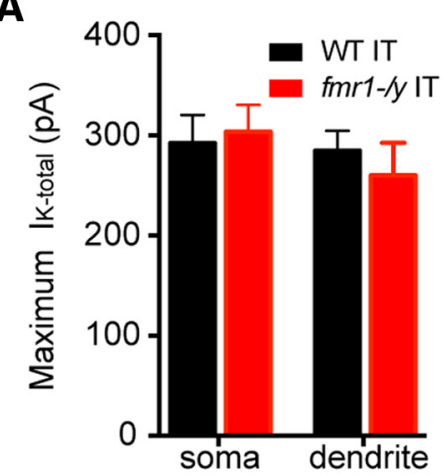

C

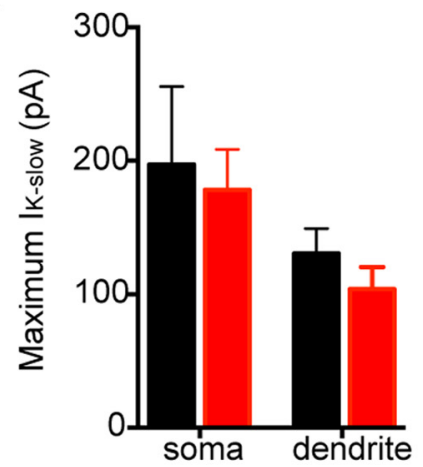

B

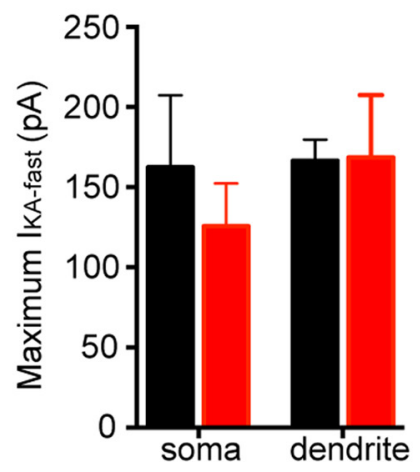

D

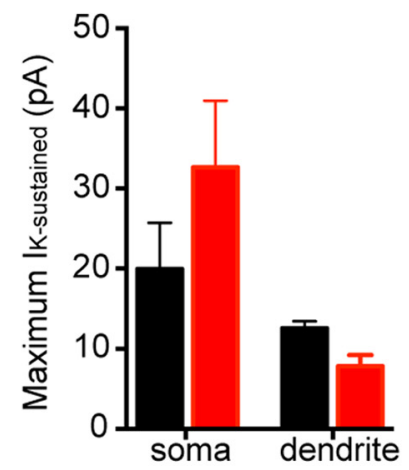

E
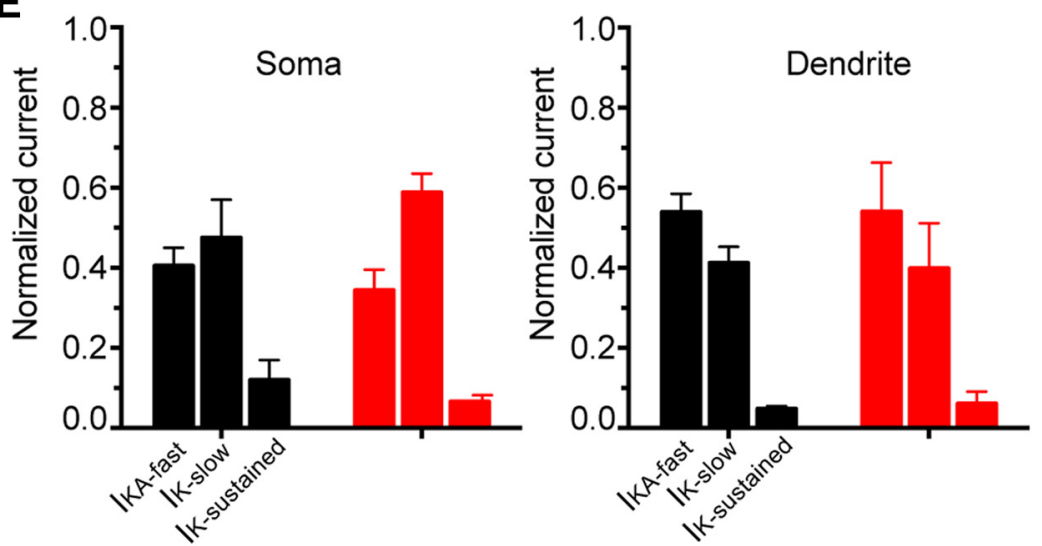

Figure 7. $I_{K}$ is not different in IT neurons in fmr1-/y versus WT mice. At the soma and dendrite there were no differences in the maximum amplitude of $(\boldsymbol{A}) I_{\mathrm{K} \text {-total }},(\boldsymbol{B}) I_{\mathrm{KA} \text {-fast }},(\boldsymbol{C}) I_{\mathrm{K} \text {-slow }}$, or $(\boldsymbol{D}) I_{\mathrm{K} \text {-sustained }}$ in fmr1-/y versus WT IT neurons. $\boldsymbol{E}$, Summary of somatic and dendritic $I_{\mathrm{K}}$ in WT ( $n=18$ somas from 12 mice and 5 dendrites from 5 mice; $180-330 \mu \mathrm{m}, 250 \pm 20.1 \mu \mathrm{m}$ from soma) and fmr1-/y IT $(n=11$ somas from 8 mice and 5 dendrites from 5 mice; $170-270 \mu \mathrm{m}, 215 \pm 27.7 \mu \mathrm{m}$ from soma) neurons.

ANOVA). Thus, the hyperpolarizing shift in the activation of $I_{\text {KA-fast }}$ normally observed from soma to dendrite in WT neurons is absent in fmr1-/y neurons. These data suggest that although there is no difference in maximum $I_{\text {KA-fast }}$ in the dendrites of fmr1-/y versus WT PT neurons, there may subtle differences in voltage dependence of activation.

\section{Altered action potential generation in fmr1-/y L5 PT neurons of mPFC}

$\mathrm{K}^{+}$channels modulate several aspects of neural function, including the dynamics of action potential threshold. Changes to threshold, also known as threshold accommodation, can be mediated through the recruitment of $\mathrm{K}^{+}$ channels, in addition to $\mathrm{Na}^{+}$channel inactivation (Hodgkin and Huxley, 1952). Kv4 and Kv1 subunits have both been implicated in regulating neural excitability by setting the threshold for action potential generation (Bekkers and Delaney, 2001; Kim et al., 2005; Higgs and Spain, 2011; Carrasquillo et al., 2012). Because we observed somatic differences consistent with alterations to these two $\mathrm{K}^{+}$ channels, we predicted that threshold dynamics would be altered in L5 PT neurons in $\mathrm{mPFC}$.

To test this hypothesis, we injected current of varied duration at the soma of L5 PT neurons in both genotypes (WT: $n=20$ cells from 11 mice; fmr1-/y: $n=23$ cells from 9 mice). The current amplitude for a given duration was 
A
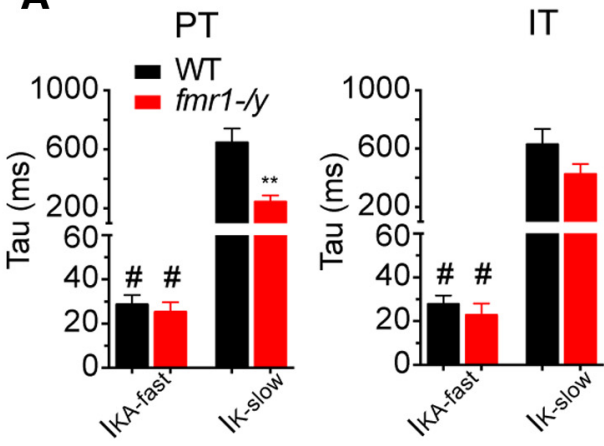

C

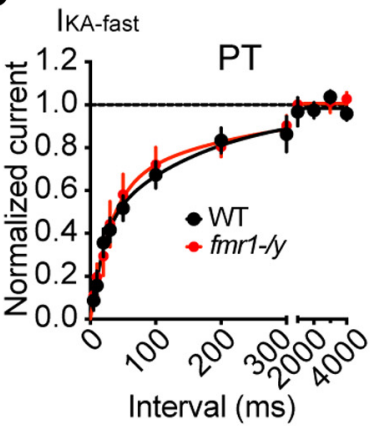

IT

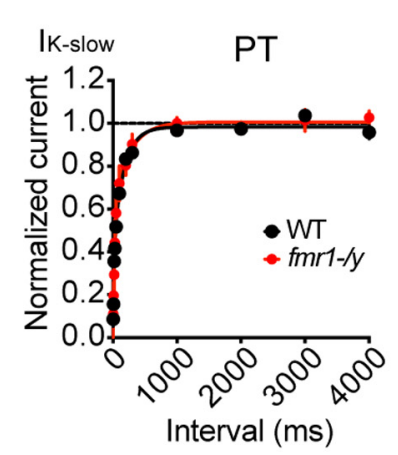

D

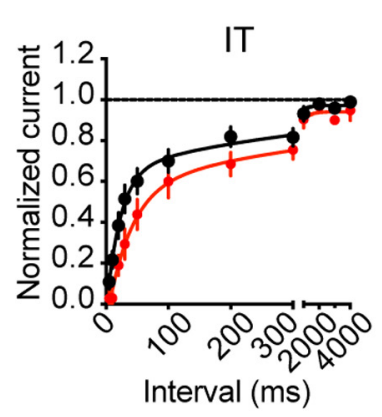

F

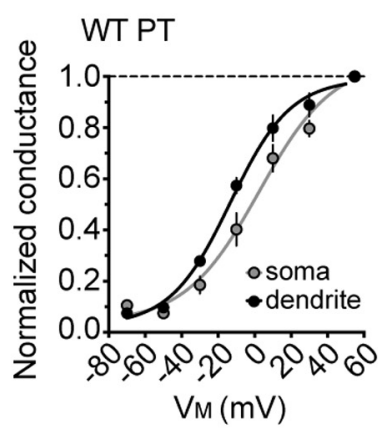

G

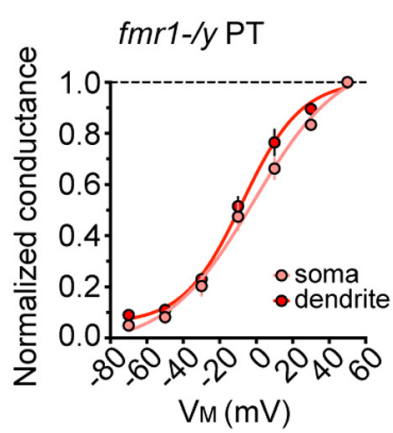

IT

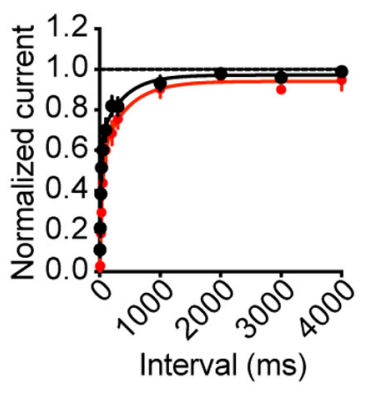

E

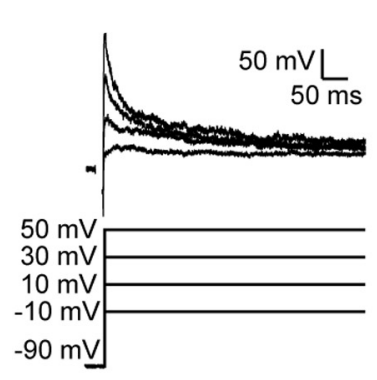

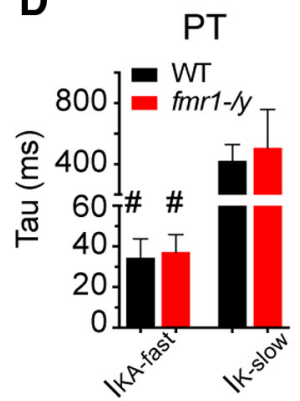

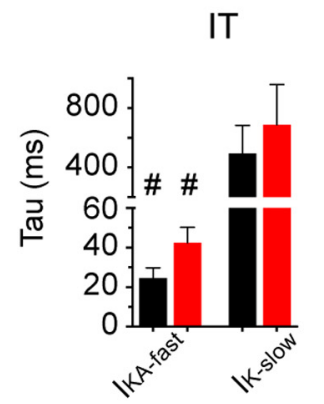

H

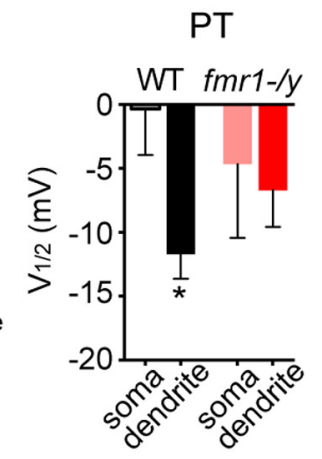

Figure 8. Kinetic properties of $\mathbf{K}^{+}$channels in L5 neurons of PFC. $\boldsymbol{A}$, The time constant of inactivation of $I_{\mathrm{K} \text {-slow }}$ is significantly longer than $I_{\text {KA-fast }}$ in both PT (left) and IT (right) neurons. \#p $<0.05$. Additionally, in PT neurons, the time constant of inactivation of $I_{\text {KA-slow }}$ was shorter in fmr1-/y neurons compared with WT. $* \mathrm{p}<0.01$. $\boldsymbol{B}$, Amount of $\mathrm{I}_{\mathrm{K} \text {-slow }}$ recovered from inactivation, normalized to maximum current, in PT (left) and (right) IT neurons. $\boldsymbol{C}$, Amount of $I_{\text {KA-fast }}$ recovered from inactivation, normalized to maximum current, in PT (left) and IT neurons (right). $\boldsymbol{D}$, Time constant for recovery from inactivation data plotted in $\boldsymbol{B}$ and $\boldsymbol{C}$ for PT (left) and IT (right) neurons. $\# p<0.05$ post hoc comparison between current types in same genotype. $\boldsymbol{E}$, Protocol for measuring voltage dependence of $I_{\mathrm{KA}} . \boldsymbol{F}$, In WT neurons, the steady-state activation curve is shifted to hyperpolarized potentials in the dendrite relative to the soma. $\mathbf{G}$, In contrast, there is no difference in the activation curves between the soma and dendrite in fmr1-/y neurons. $\boldsymbol{H}$, the $V_{1 / 2}$ of activation is hyperpolarized in the dendrite compared with the soma in WT neurons. In contrast, there is no difference in the $V_{1 / 2}$ of activation between the soma and dendrite in fmr1-/y neurons.

adjusted to be just-threshold for the generation of an action potential (Fig. 10A). Action potential threshold varied as a function of current duration in both genotypes $(p$ $<0.001$, ANOVA $\left.{ }^{\prime}\right)$. However, for durations greater than 6 $\mathrm{ms}$, spike threshold was significantly more hyperpolarized in fmr1-ly PT neurons compared with WT neurons $(p<$ 0.01 ; post hoc comparisons ${ }^{h^{\prime}}$; Fig. $10 A-C$ ). Furthermore, the current required to generate an action potential was significantly lower in fmr1-/y compared with WT neurons at all current durations $\left(p<0.001\right.$, ANOVA $\left.^{i}\right)$. Differences in $\mathrm{Na}^{+}$channel availability can produce differences in action potential threshold (Hodgkin and Huxley, 1952). However, there was no significant difference in the maximum rate of rise of action potentials in WT versus fmr1-/y neurons, a spike parameter sensitive to $\mathrm{Na}^{+}$channel availability $\left(p=0.30\right.$; ANOVA $\mathrm{i}^{\prime}$; Colbert et al., 1997). There was also no difference in action potential amplitude between genotypes ( $p=0.59$; ANOVA). Finally, there were no differences in action potential threshold between WT and fmr1-/y IT neurons $\left(p=0.31\right.$; ANOVA; Fig. $\left.10 D^{k^{\prime}}\right)$. 
A

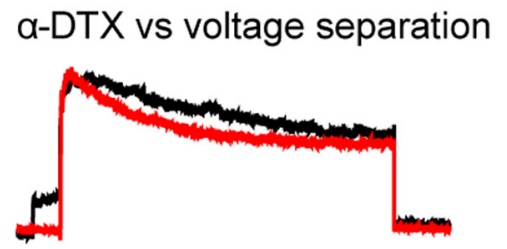

$50 \mathrm{pA} \underset{250 \mathrm{~ms}}{\longleftarrow}$

B
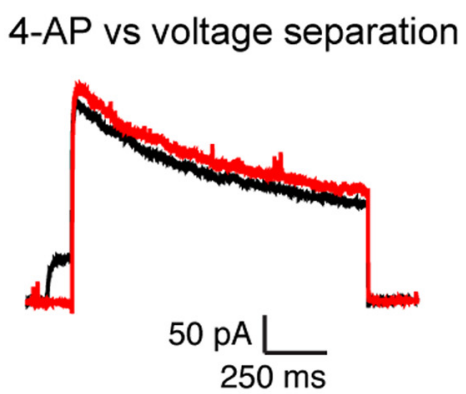

C

$\mathrm{Ba}^{2+}$ vs voltage separation

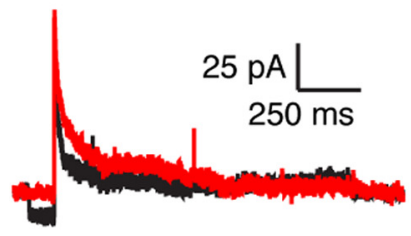

D

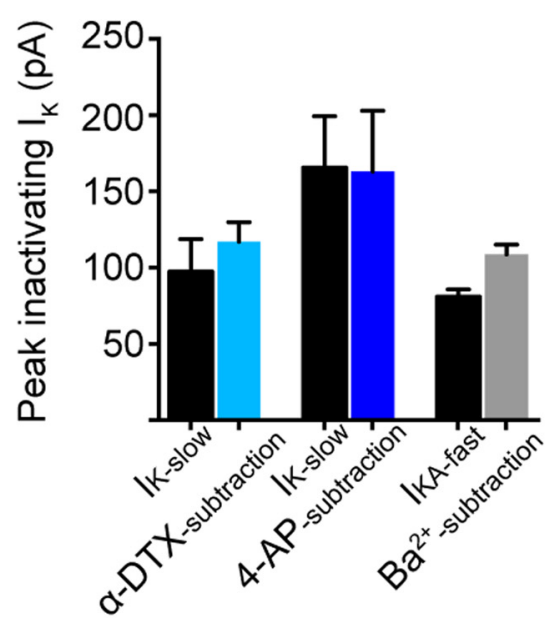

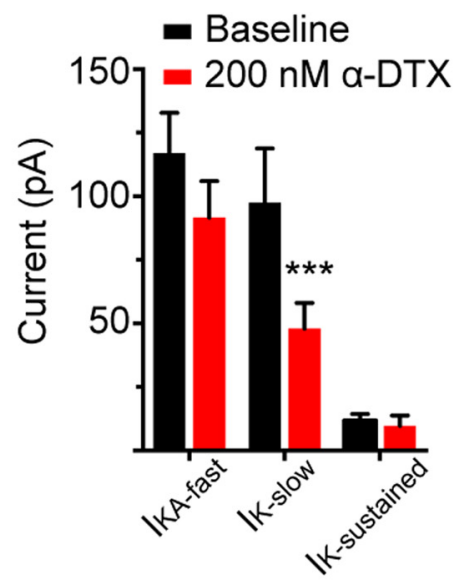
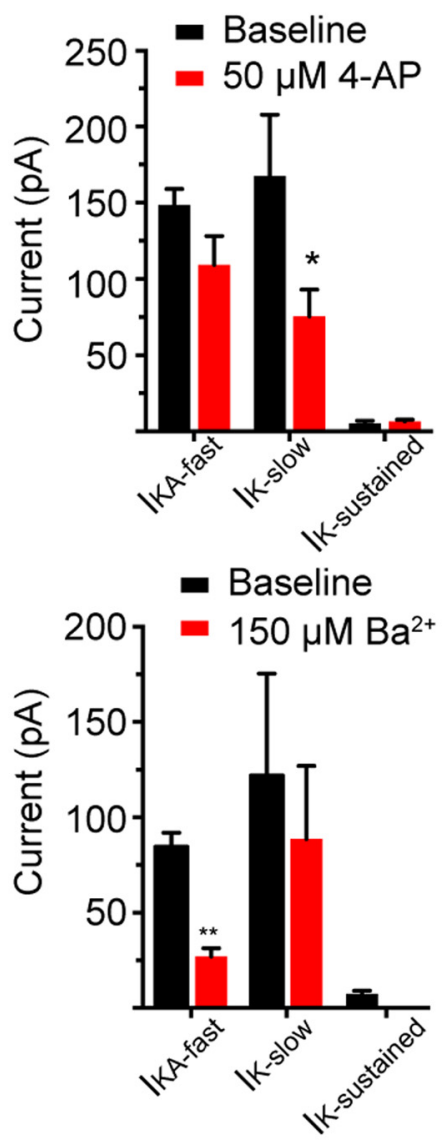

Figure 9. Sensitivity of $\mathbf{K}^{+}$currents to $\mathbf{K}^{+}$channel blockers. $\boldsymbol{A}$, Sample sweeps recorded from the same patch comparing the

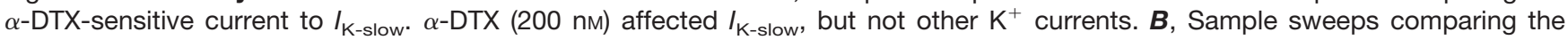


continued

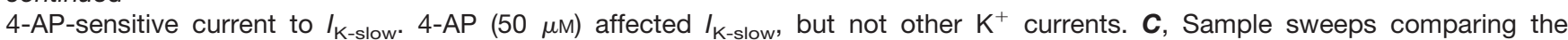
$\mathrm{Ba}^{2+}$-sensitive current to $I_{\mathrm{KA} \text {-fast }}$. $\mathrm{Ba}^{2+}(150 \mu \mathrm{M})$ affected $I_{\mathrm{K} \text {-slow }}$, but not other $\mathrm{K}^{+}$currents. $\boldsymbol{D}$, Summary of currents obtained via voltage separation versus $\mathrm{K}^{+}$channel blockers. The amplitude of 4 -AP and $\alpha$-DTX-sensitive current is similar to the amplitude of $I_{\mathrm{K} \text {-slow }}$ obtained via voltage separation, whereas the amplitude of the $\mathrm{Ba}^{2+}$-sensitive current is similar to $I_{\mathrm{KA} \text {-fast }}$.

Together with our outside-out patch recordings, these data suggest that differences in $\mathrm{K}^{+}$channel expression in PT, but not IT neurons, contribute to alterations in spike threshold dynamics in the fmr1-/y mouse mPFC, resulting in an increase in excitability.

As an additional test that differences in $\mathrm{K}^{+}$channel function contribute to differences in excitability, we measured the sensitivity of threshold to $50 \mu \mathrm{M} 4-\mathrm{AP}$ and 150 $\mu \mathrm{M} \mathrm{Ba}{ }^{2+}$, and $200 \mathrm{~nm} \alpha$-DTX. Bath application of $50 \mu \mathrm{M}$ 4-AP produced a decrease in threshold for all but the shortest current durations in both genotypes (WT and fmr1-/y: $n=6$ cells from 4 mice; $p<0.01$, ANOVA $\left.{ }^{\prime}\right)$. This effect, however, was larger in WT compared with fmr1-/y neurons, consistent with a lower contribution of $\mathrm{K}_{\mathrm{v}}$ 1containing channels and in agreement with our current measurements ( $p<0.01$; Fig. $11 A^{\mathrm{m}^{\prime}}$ ). Similarly, $200 \mathrm{~nm}$ $\alpha$-DTX produced a larger affect on threshold in WT compared with fmr1-/y neurons (WT and fmr1-/y: $n=5$ cells from 4 mice; $p=0.02$; ANOVA; Fig. 11 $\left.B^{n^{\prime}}\right) . \mathrm{Ba}^{2+}(150 \mu \mathrm{M})$ produced a small but significant decrease in threshold for all but the shortest current durations in both genotypes (WT and fmr1-/y: $\mathrm{n}=8$ from 4 and 5 mice, respectively; $p$ $<0.01$; ANOVA; Fig. $11 C^{\circ}$ ). Interestingly, in WT mice the effect of 4-AP and $\alpha$-DTX was larger than that of $\mathrm{Ba}^{2+}(p$ $<0.001$, ANOVA $^{\mathrm{p}^{\prime}}$ ), whereas in fmr1-/y mice there was no difference in the effect of these $\mathrm{K}^{+}$channel blockers $(p=$ 0.55, ANOVA; Fig. 11D $\left.{ }^{q^{\prime}}\right)$. These data suggest that in fmr1-/y PT neurons, a decrease in Kv1-mediated $\mathrm{K}^{+}$current contributes to an increase in excitability.

\section{Discussion}

We have provided evidence for neuron-type-specific channelopathies within a single brain region in FXS. We observed several differences in the functional expression of ion channels in L5 neurons of mPFC in the fmr1-/y mouse (Fig. 12). At the soma and dendrite, we observed differences in the subthreshold properties of fmr1-/y PT neurons consistent with a decrease in $I_{\mathrm{h}}$ compared with WT neurons. These differences were largely eliminated by the application of the h-channel blocker ZD7288, suggesting that they were mediated, in part, by differences in h-channels. Consistent with this, we observed less $I_{\mathrm{h}}$ at the distal dendrite of fmr1-/y PT neurons, suggesting that there is a reduction in functional h-channels. Additionally, we found alterations to several $\mathrm{K}^{+}$channels at the soma of PT neurons. Compared with WT neurons, fmr1-/y neurons possessed greater maximum fast-inactivating A-type $\mathrm{K}^{+}$current, but less slow-inactivating $\mathrm{K}^{+}$current. The kinetics and pharmacologic sensitivity of these currents was consistent with $\mathrm{Kv} 4$ and $\mathrm{Kv} 1$ containing channels, respectively. In contrast to $\mathrm{PT}$ neurons, there were no genotypic differences in the maximum amplitude of these $\mathrm{K}^{+}$currents at the soma of IT neurons. As a functional consequence of altered somatic $\mathrm{K}^{+}$channel function in PT neurons, we observed an increase in excitability.

These findings expand on previous reports of channelopathies in various brain regions by demonstrating neuron specific phenotypes within a brain region (Brager and Johnston, 2014). In L5B neurons of somatosensory cortex a decrease in $\mathrm{h}$-channel expression, together with altered BK channel function, contributes to a lowered threshold for dendritic $\mathrm{Ca}^{2+}$ electrogenesis (Zhang et al., 2014). In contrast to somatosensory cortex, there is an increase in h-channel expression in CA1 pyramidal neurons in the fmr1-/y mouse (Brager et al., 2012). Additionally, in CA1 pyramidal neurons, there is a decrease in Kv4-mediated A-type $\mathrm{K}^{+}$current (Routh et al., 2013). Our data, together with these previously published findings, suggest that in FXS the function of a given ion channel can be affected in opposite ways depending upon brain region. More importantly, the absence of differences in $\mathrm{K}^{+}$channel function in IT neurons suggests that neuron-specific channel phenotypes can occur even within a brain region, between different classes of principal neurons (Fig. 12). Alterations to other channel types reported in various brain regions may similarly display neuron-type specificity.

\section{Identity of $\mathrm{K}^{+}$channels altered in $\mathrm{mPFC}$}

$\mathrm{Kv} 1$ and Kv4 containing channels contribute to transient $\mathrm{K}^{+}$currents (Coetzee et al., 1999). Although the details depend upon which auxiliary subunits are present, Kv4 channels inactivate and recover from inactivation an order of a magnitude faster than Kv1 channels (Castellino et al., 1995; An et al., 2000; Jerng et al., 2004; Kim et al., 2008). Thus, the $I_{\mathrm{KA} \text {-fast }}$ we observed is consistent with $\mathrm{Kv} 4$ containing channels whereas the $I_{\mathrm{K} \text {-slow }}$ is consistent with Kv1 channels. Several subunits within the Kv1 and Kv4 families can contribute to transient $\mathrm{K}^{+}$currents (Coetzee et al., 1999). There is evidence that Kv4.2, 4.3, and 1.4 contribute to transient $\mathrm{K}^{+}$currents at the soma of cortical pyramidal neurons (Carrasquillo et al., 2012). In addition, Kv1.2 containing channels contribute to a slowly inactivating $\mathrm{K}^{+}$current at the soma (Bekkers and Delaney, 2001). All of these subunits have been reported to contribute to action potential threshold and thus alterations to any of these subunits could contribute to differences in $I_{\mathrm{K}}$ and excitability we observe (Bekkers and Delaney, 2001; Kim et al., 2005; Kole et al., 2007; Higgs and Spain, 2011). Regardless of the subunit, the differences in maximum current we observed are consistent with a decrease in the number of Kv1 channels and an increase in Kv4 channels in PT neurons of mPFC in the fmr1-/y mouse.

\section{Potential mechanisms}

Brain region-specific channel phenotypes in FXS could be caused by a primary deficiency in an FMRP-mediated 
A
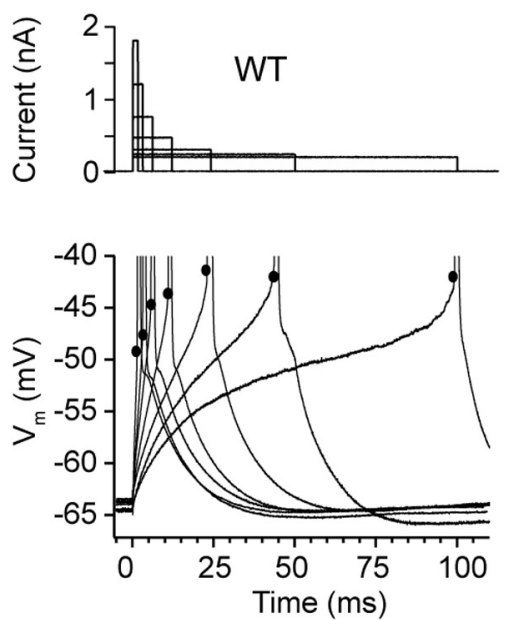

B

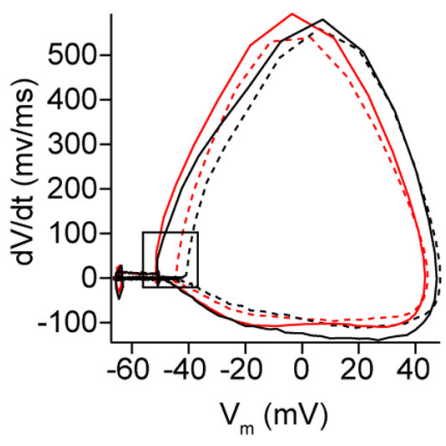

C

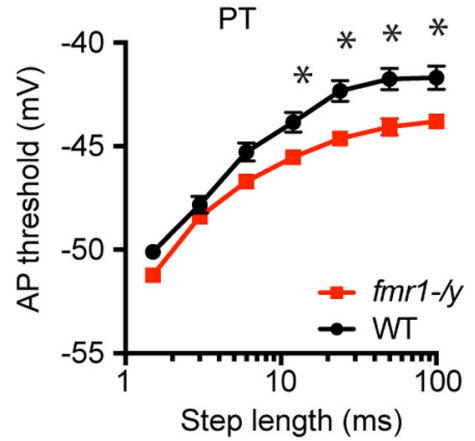

PT
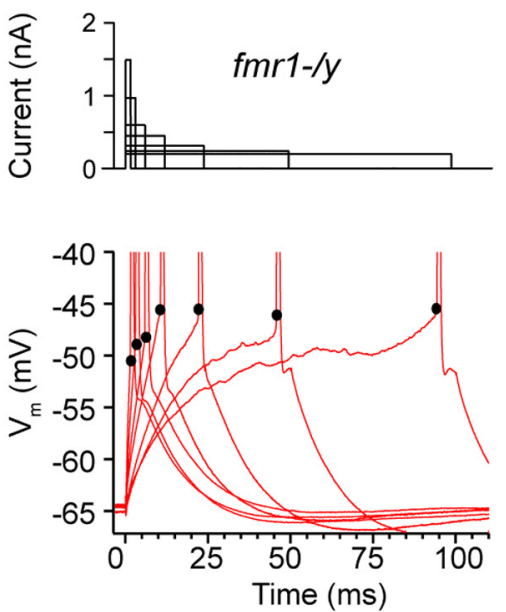

$\mathrm{PT}$

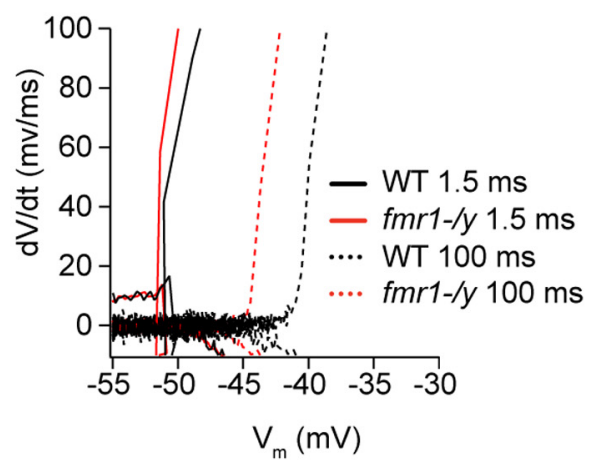

D

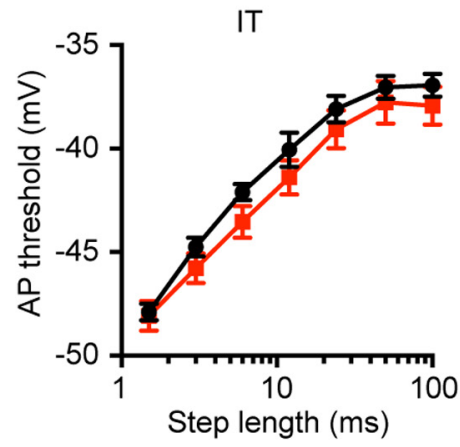

Figure 10. Fmr1-/y PT neurons are more excitable compared with WT neurons. A, The threshold for action potential generation in WT and fmr1-ly neurons was measured in response to just threshold current injections of increasing duration. Sample action potentials for each genotype are shown below. $\boldsymbol{B}$, Phase plane plot of action potentials in fmr1-/y and WT PT neurons in response to 1.5 and 100 ms current injection. $\mathbf{C}$, fmr1-/y neurons displayed a lower threshold for action potential generation for all current injections longer than $6 \mathrm{~ms}$. $\boldsymbol{D}$, There were no differences in threshold between fmr1-/y and WT IT neurons. $* \mathrm{p}<0.01$ comparison between genotypes.

process within the cell. FMRP is an mRNA binding protein and has been shown to negatively regulate protein synthesis through ribosomal stalling (Li et al., 2001; Zalfa et al., 2003; Darnell et al., 2011). Consequently, the absence of FMRP could lead to elevated expression of ion channel proteins and/or their regulatory subunits. More recent evidence suggests that FMRP can also promote the translation of certain mRNAs (Bechara et al., 2009; Fähling et al., 2009; Gross et al., 2011). Thus, the absence of FMRP might then reduce the expression of ion channel proteins. In addition to its role in translation, FMRP participates in the activity-dependent transport of mRNA granules from the soma to axonal and dendritic locations (Antar et al., 2004; Kanai et al., 2004; Dictenberg et al., 


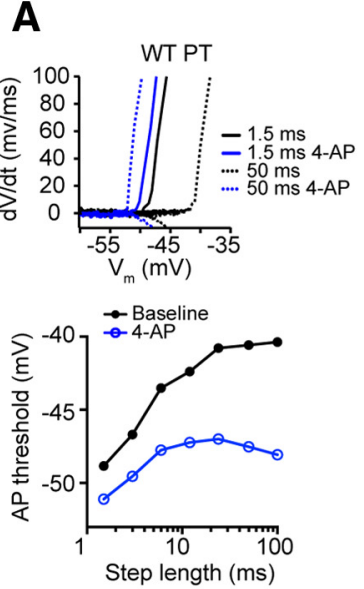

B
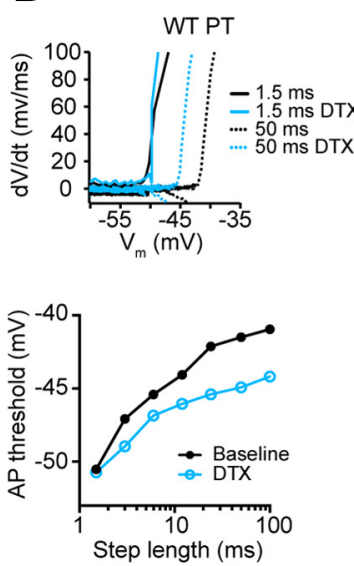
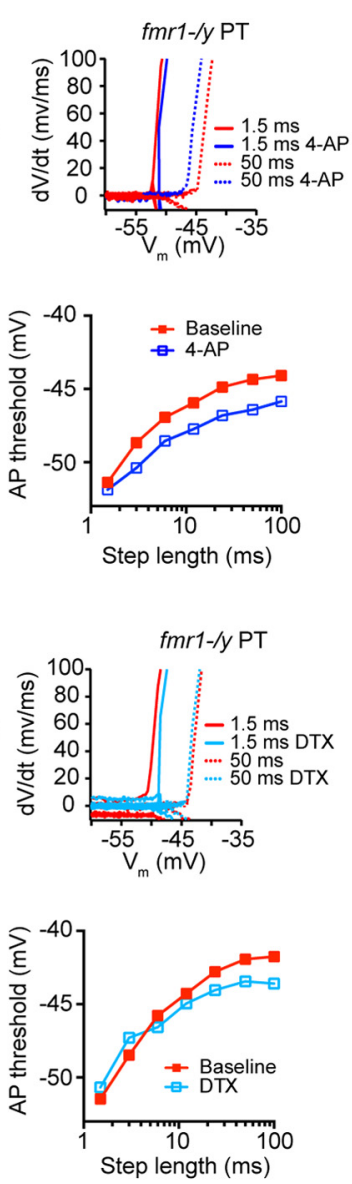

C
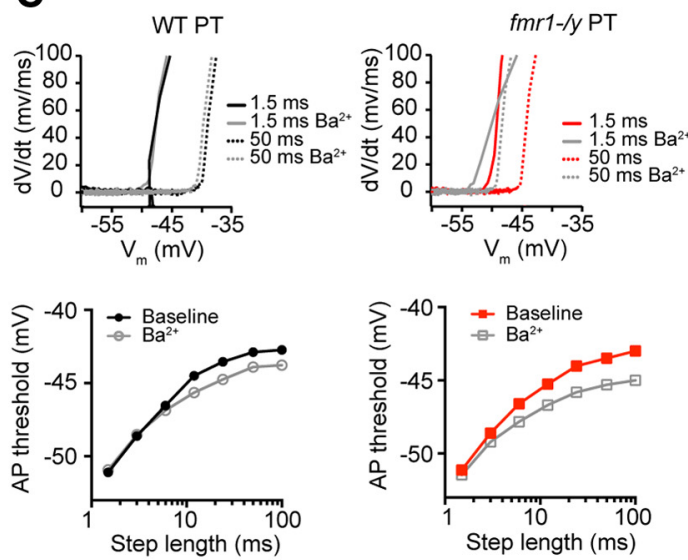

D
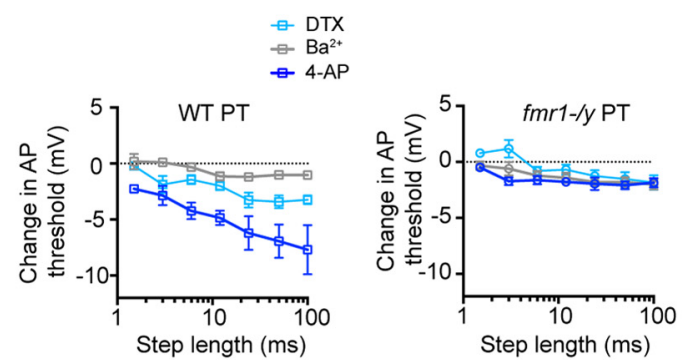

Figure 11. Fmr1-/y neurons are less sensitive to Kv1 channel blockers compared with WT neurons. $\boldsymbol{A}$, Phase plane plots for action potentials generated in response to 1.5 and $50 \mathrm{~ms}$ current injections before and after $50 \mu \mathrm{M}$ 4-AP application. 4-AP decreased threshold in both genotypes, but more so in WT neurons. B. Phase plane plots for action potentials generated before and after 200 nм $\alpha$-DTX application. $\alpha$-DTX decreased threshold in both genotypes, but more so in WT neurons. $\boldsymbol{C}$, Phase plane plots for action potentials generated before and after $150 \mu \mathrm{M} \mathrm{Ba}{ }^{2+}$ application. $\mathrm{Ba}^{2+}$ decreased action potential threshold in both genotypes. $\boldsymbol{D}$, 4-AP and $\alpha$-DTX application had a larger effect on action potential threshold compared with $\mathrm{Ba}^{2+}$ in WT neurons. In contrast, 4-AP and $\alpha$-DTX had the same effect on action potential threshold compared with $\mathrm{Ba}^{2+}$ in $\mathrm{fmr} 1-/ y$ neurons. For current steps longer than 6 ms, there was significant difference in the effect of 4-AP and/or $\alpha$-DTX on threshold between WT and fmr1-/y mice.

2008). The absence of FMRP could therefore result in the trapping of ion channel mRNAs at the soma or the mislocalization of mRNAs and the encoded proteins. Both h-channel and A-type $\mathrm{K}^{+}$channel mRNAs are known targets of FMRP (Gross et al., 2011; Lee et al., 2011; Darnell et al., 2011). Therefore, the channel phenotypes observed in FXS could be because of either of these mRNA regulatory processes. Lastly, FMRP can directly bind to target proteins, including ion channel subunits. Consequently, the absence of FMRP could alter the biophysical properties or surface expression of ion channels by promoting inappropriate subunit assemblies (Brown et al., 2010; Deng et al., 2013). It is noteworthy that in order to sufficiently explain the divergent channel phenotype we observe, these cellular processes would have to promote or suppress the function of a given ion channel in a neuron-specific manner.

Alternatively, the differences in channel function we observe could be the result of secondary changes in response to altered processes extrinsic to the cell. Both $I_{\mathrm{h}}$ and $I_{K A}$ undergo synaptic-driven changes (Frick et al., 2004; Fan et al., 2005; Brager and Johnston, 2007; Losonczy et al., 2008). Thus, a potential cell extrinsic mechanism could involve changes in synaptic input to mPFC neurons that result in changes in ion channel function opposite to those that occur in CA1. Indeed there is evidence that synaptic input to neocortical and hippocampal pyramidal neurons is altered in the fmr1-/y mouse (Bureau et al., 2008; Gibson et al., 2008; Hays et al., 2011; Krueger et al., 2011; Testa-Silva et al., 2012; Patel et al., 2013; Tyzio et al., 2014). In addition, the function of both $I_{\mathrm{h}}$ and $I_{\mathrm{KA}}$ are affected by neuromodulation (Hoffman and Johnston, 1999; Carr et al., 2007; Dembrow et al., 2010). Thus, the divergent channel phenotypes observed in CA1 and neocortex could be caused by differences in neuromodulation. Determining whether neuron-type-specific alterations to ion channel function are caused by a cell autonomous or cell extrinsic mech- 


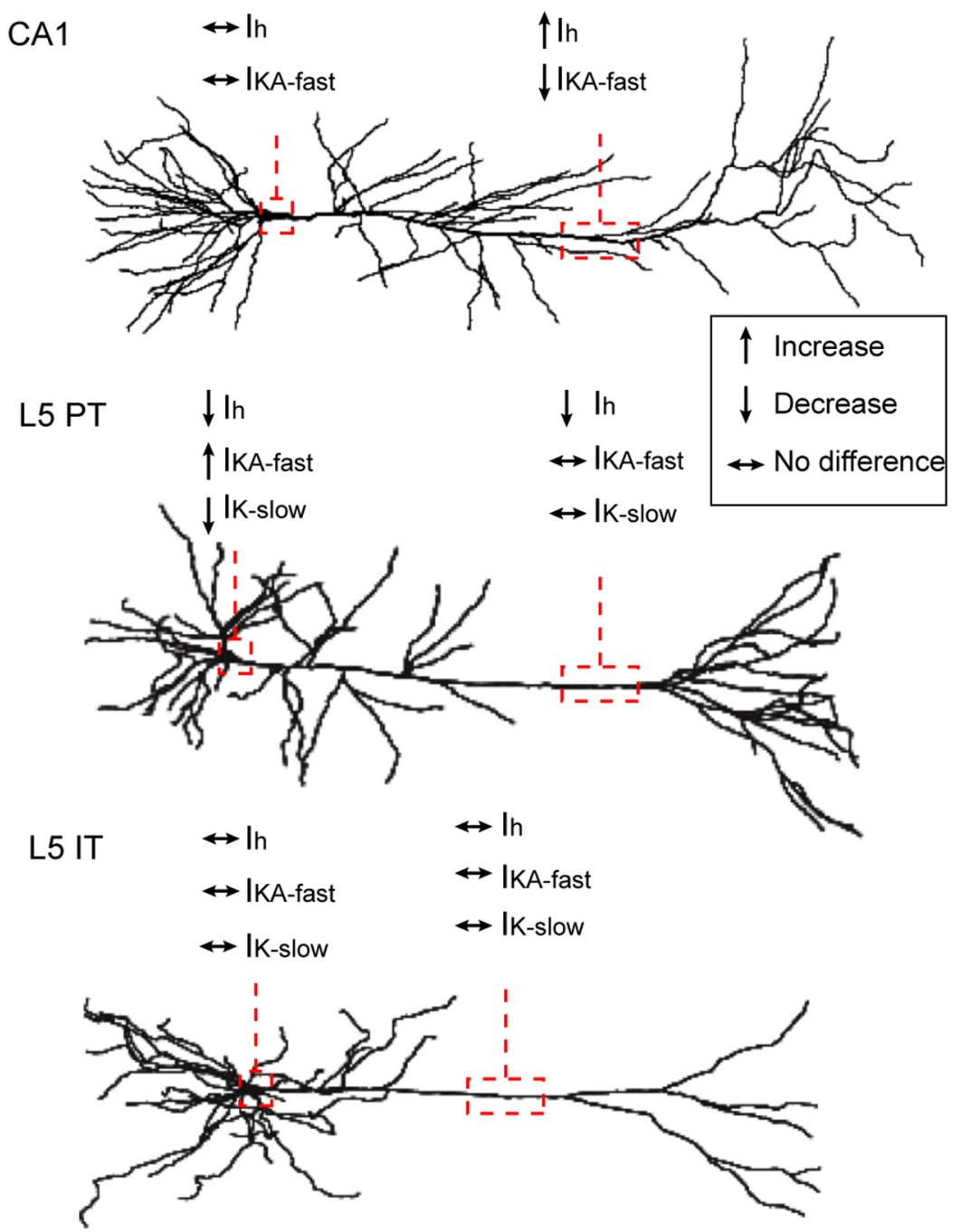

Figure 12. Summary of neuron type-specific channel phenotypes observed in the fmr1-/y mouse. Dendritic and somatic $I_{\mathrm{h}}$, $I_{\mathrm{KA}}$-fast, and $I_{\mathrm{K}}$-slow levels in the fmr1-/y mouse relative to WT in CA1 pyramidal neurons (Brager et al., 2012; Routh et al., 2013), L5 PT neurons of PFC and IT neurons of PFC. There is also a decrease in $I_{\mathrm{h}}$ in the dendrites of L5 neurons of somatosensory cortex (data not shown; Zhang et al, 2014). Upward arrow indicates increase relative to WT. Downward arrow indicates decrease relative to WT. Horizontal arrow indicates no difference relative to WT.

anism (eg, differences in network activity) is a difficult challenge, yet fundamental to our understanding of the neurobiology of FXS.

\section{Functional implications}

The combined effects of the channel phenotypes we observe could have a substantial impact on mPFC function. PT neurons receive synaptic input in L1 from various sources and the presence of $I_{\mathrm{h}}$ greatly influences the transfer of these inputs to the soma (Dembrow et al., 2015). Specifically, $I_{\mathrm{h}}$ contributes to the filtering properties of the membrane such that inputs arriving in the theta frequency range are selectively transferred to the soma (Ulrich, 2002; Cook et al., 2007). Additionally, $I_{\mathrm{h}}$ compensates for distance dependent temporal delays imposed by the dendrite, ensuring that distal inputs arrive at the soma with a similar latency to proximal ones (Vaidya and Johnston, 2013). This has the effect of narrowing the temporal window under which synaptic input arriving at different dendritic locations can summate at the soma to drive an action potential (Dembrow et al., 2015). Thus, the decrease in $I_{\mathrm{h}}$ we observe in the fmr1-/y mouse could: (1) affect the frequency preference of PT neurons to synaptic input, and (2) increase integration at the soma of asynchronous dendritic synaptic inputs. Consequently, fmr1-/y PT neurons may function as temporal integrators of synaptic input, in contrast with WT PT neurons, which function as coincidence detectors (Dembrow et al., 2015).

These changes in $I_{\mathrm{h}}$ could work synergistically with $\mathrm{K}^{+}$ channel alterations to make fmr1-/y PT neurons generally more responsive to synaptic input. $\mathrm{K}^{+}$channels affect the threshold for spike generation in part by influencing the voltage at the axon initiation site (Bekkers and Delaney, 2001; Kole et al., 2007). Like $\mathrm{h}$-channels, $\mathrm{K}^{+}$channels contribute to the band pass filtering properties of the membrane. Thus, the changes in $\mathrm{K}^{+}$channels we observe 
could also decrease the preference of PT neurons for high-frequency input as has been observed upon blockade of Kv1 channels in L2/3 neurons (Higgs and Spain, 2011). Together with changes to synaptic input, these changes may contribute to altered up-states observed in cortical pyramidal neurons in the fmr1-/y mouse (Hays et al., 2011; Gonçalves et al., 2013).

FXS patients display behavioral deficits associated with PFC dysfunction, including hyperactivity, attention deficits, impulsivity, and behavioral inflexibility. The channel phenotypes we describe here may thus contribute to these behavioral phenotypes. Finally, our findings of celltype-specific phenotypes highlights the challenges associated with developing effective treatment strategies in FXS. A critical implication of our findings is that existing therapies that target a given channel phenotype, although effective in treating one feature of FXS could simultaneously exacerbate others. Understanding the mechanisms of these neuron/brain region-specific effects in FXS may prove critical in developing treatment strategies.

\section{References}

An WF, Bowlby MR, Betty M, Cao J, Ling HP, Mendoza G, Hinson JW, Mattsson KI, Strassle BW, Trimmer JS, Rhodes KJ (2000) Modulation of A-type potassium channels by a family of calcium sensors. Nature 403:553-556. CrossRef Medline

Antar LN, Afroz R, Dictenberg JB, Carroll RC, Bassell GJ (2004) Metabotropic glutamate receptor activation regulates fragile $x$ mental retardation protein and FMR1 mRNA localization differentially in dendrites and at synapses. J Neurosci 24:2648-2655. CrossRef Medline

Avesar D, Gulledge AT (2012) Selective serotonergic excitation of callosal projection neurons. Front Neural Circuits 6. CrossRef Medline

Bechara EG, Didiot MC, Melko M, Davidovic L, Bensaid M, Martin P, Castets M, Pognonec P, Khandjian EW, Moine H, Bardoni B (2009) A novel function for fragile $X$ mental retardation protein in translational activation. PLoS Biol 7:e16 CrossRef Medline

Bekkers JM (2000) Distribution and activation of voltage-gated potassium channels in cell-attached and outside-out patches from large layer 5 cortical pyramidal neurons of the rat. $J$ Physiol 525:611-620. Medline

Bekkers JM, Delaney AJ (2001) Modulation of excitability by alphadendrotoxin-sensitive potassium channels in neocortical pyramidal neurons. J Neurosci 21:6553-6560. Medline

Bernard C, Anderson A, Becker A, Poolos NP, Beck H, Johnston D (2004) Acquired dendritic channelopathy in temporal lobe epilepsy. Science 305:532-535. CrossRef Medline

Bhakar AL, Dölen G, Bear MF (2012) The pathophysiology of fragile $X$ (and what it teaches us about synapses). Annu Rev Neurosci 35:417-443. CrossRef Medline

Brager DH, Akhavan AR, Johnston D (2012) Impaired dendritic expression and plasticity of h-channels in the fmr1(-/y) mouse model of fragile X syndrome. Cell Rep 1:225-233. CrossRef Medline

Brager DH, Johnston D (2007) Plasticity of intrinsic excitability during long-term depression is mediated through mGluR-dependent changes in $I_{\mathrm{h}}$ in hippocampal CA1 pyramidal neurons. J Neurosci 27:13926-13937. CrossRef Medline

Brager DH, Johnston D (2014) Channelopathies and dendritic dysfunction in fragile X syndrome. Brain Res Bull 103:11-17. CrossRef Medline

Brown MR, Kronengold J, Gazula V-R, Chen Y, Strumbos JG, Sigworth FJ, Navaratnam D, Kaczmarek LK (2010) Fragile X mental retardation protein controls gating of the sodium-activated potassium channel Slack. Nat Neurosci 13:819-821. CrossRef Medline
Bureau I, Shepherd GMG, Svoboda K (2008) Circuit and plasticity defects in the developing somatosensory cortex of Fmr1 knockout mice. J Neurosci 28:5178-5188. CrossRef

Carr DB, Andrews GD, Glen WB, Lavin A (2007) 2-Noradrenergic receptors activation enhances excitability and synaptic integration in rat prefrontal cortex pyramidal neurons via inhibition of $\mathrm{HCN}$ currents. J Physiol 584:437-450. CrossRef Medline

Carrasquillo Y, Burkhalter A, Nerbonne JM (2012) A-type K+ channels encoded by $\mathrm{Kv} 4.2, \mathrm{Kv} 4.3$, and $\mathrm{Kv} 1.4$ differentially regulate intrinsic excitability of cortical pyramidal neurons. J Physiol 590: 3877-3890. CrossRef Medline

Castellino RC, Morales MJ, Strauss HC, Rasmusson RL (1995) Timeand voltage-dependent modulation of a Kv1.4 channel by a betasubunit ( $\mathrm{Kv}$ beta 3 ) cloned from ferret ventricle. Am J Physiol 269:H385-H391. Medline

Castle NA, Fadous S, Logothetis DE, Wang GK (1994) Aminopyridine block of Kv1.1 potassium channels expressed in mammalian cells and Xenopus oocytes. Mol Pharmacol 45:1242-1252. Medline

Christophe E, Doerflinger N, Lavery DJ, Molnár Z, Charpak S, Audinat $E$ (2005) Two populations of layer $V$ pyramidal cells of the mouse neocortex: development and sensitivity to anesthetics. J Neurophysiol 94:3357-3367. CrossRef Medline

Coetzee WA, Amarillo Y, Chiu J, Chow A, Lau D, McCormack T, Moreno H, Nadal MS, Ozaita A, Pountney D, Saganich M, VegaSaenz de Miera E, Rudy B (1999) Molecular diversity of K+ channels. Ann N Y Acad Sci 868:233-285. Medline

Colbert CM, Magee JC, Hoffman DA, Johnston D (1997) Slow recovery from inactivation of $\mathrm{Na}+$ channels underlies the activitydependent attenuation of dendritic action potentials in hippocampal CA1 pyramidal neurons. J Neurosci 17:6512-6521. Medline

Contractor A, Klyachko VA, Portera-Cailliau C (2015) Altered neuronal and circuit excitability in fragile $X$ syndrome. Neuron 87:699715. CrossRef Medline

Cook EP, Guest JA, Liang Y, Masse NY, Colbert CM (2007) Dendriteto-soma input/output function of continuous time-varying signals in hippocampal CA1 pyramidal neurons. J Neurophysiol 98:29432955. CrossRef Medline

Darnell JC, Van Driesche SJ, Zhang C, Hung KYS, Mele A, Fraser CE, Stone EF, Chen C, Fak JJ, Chi SW, Licatalosi DD, Richter JD, Darnell RB (2011) FMRP stalls ribosomal translocation on mRNAs linked to synaptic function and autism. Cell 146:247-261. CrossRef Medline

Dembrow N, Johnston D (2014) Subcircuit-specific neuromodulation in the prefrontal cortex. Front Neural Circuits 8:54. CrossRef Medline

Dembrow NC, Chitwood RA, Johnston D (2010) Projection-specific neuromodulation of medial prefrontal cortex neurons. J Neurosci 30:16922-16937. CrossRef Medline

Dembrow NC, Zemelman BV, Johnston D (2015) Temporal dynamics of L5 dendrites in medial prefrontal cortex regulate integration versus coincidence detection of afferent inputs. J Neurosci 35: 4501-4514. CrossRef Medline

Deng P-Y, Rotman Z, Blundon JA, Cho Y, Cui J, Cavalli V, Zakharenko SS, Klyachko VA (2013) FMRP regulates neurotransmitter release and synaptic information transmission by modulating action potential duration via BK channels. Neuron 77:696-711. CrossRef

Dictenberg JB, Swanger SA, Antar LN, Singer RH, Bassell GJ (2008) A direct role for FMRP in activity-dependent dendritic mRNA transport links filopodial-spine morphogenesis to fragile $X$ syndrome. Developmental Cell 14:926-939. CrossRef Medline

Dougherty KA, Nicholson DA, Diaz L, Buss EW, Neuman KM, Chetkovich DM, Johnston D (2013) Differential expression of HCN subunits alters voltage-dependent gating of $\mathrm{h}$-channels in CA1 pyramidal neurons from dorsal and ventral hippocampus. J Neurophysiol 109:1940-1953. CrossRef Medline

Fähling M, Mrowka R, Steege A, Kirschner KM, Benko E, Förstera B, Persson PB, Thiele BJ, Meier JC, Scholz H (2009) Translational regulation of the human Achaete-scute homologue-1 by fragile $X$ 
mental retardation protein. Journal of Biological Chemistry 284: 4255-4266. CrossRef Medline

Fan Y, Fricker D, Brager DH, Chen X, Lu H-C, Chitwood RA, Johnston D (2005) Activity-dependent decrease of excitability in rat hippocampal neurons through increases in /h. Nat Neurosci 8:1542-1551. CrossRef

Frick A, Magee J, Johnston D (2004) LTP is accompanied by an enhanced local excitability of pyramidal neuron dendrites. Nat Neurosci 7:126-135. CrossRef Medline

Gasparini S, Losonczy A, Chen X, Johnston D, Magee JC (2007) Associative pairing enhances action potential back-propagation in radial oblique branches of CA1 pyramidal neurons. J Physiol 580: 787-800. CrossRef Medline

Gee S, Ellwood I, Patel T, Luongo F, Deisseroth K, Sohal VS (2012) Synaptic activity unmasks dopamine D2 receptor modulation of a specific class of layer $\mathrm{V}$ pyramidal neurons in prefrontal cortex. $J$ Neurosci 32:4959-4971. CrossRef Medline

Gibson JR, Bartley AF, Hays SA, Huber KM (2008) Imbalance of neocortical excitation and inhibition and altered UP states reflect network hyperexcitability in the mouse model of fragile $X$ syndrome. J Neurophysiol 100:2615-2626. CrossRef Medline

Gonçalves JT, Anstey JE, Golshani P, Portera-Cailliau C (2013) Circuit level defects in the developing neocortex of fragile $\mathrm{X}$ mice. Nat Neurosci 16:903-909. CrossRef Medline

Gross C, Yao X, Pong DL, Jeromin A, Bassell GJ (2011) Fragile X mental retardation protein regulates protein expression and mRNA translation of the potassium channel Kv4.2. J Neurosci 31:56935698. CrossRef Medline

Hagerman RJ, Ono MY, Hagerman PJ (2005) Recent advances in fragile $X$ : a model for autism and neurodegeneration. Curr Opin Psychiatry 18:490-496. CrossRef Medline

Harris-Warrick RM, Coniglio LM, Levini RM, Gueron S, Guckenheimer J (1995) Dopamine modulation of two subthreshold currents produces phase shifts in activity of an identified motoneuron. J Neurophysiol 74:1404-1420. Medline

Harvey AL (2001) Twenty years of dendrotoxins. Toxicon 39:15-26. Medline

Hattox AM, Nelson SB (2007) Layer V neurons in mouse cortex projecting to different targets have distinct physiological properties. J Neurophysiol 98:3330-3340. CrossRef Medline

Hays SA, Huber KM, Gibson JR (2011) Altered neocortical rhythmic activity states in Fmr1 $\mathrm{KO}$ mice are due to enhanced mGluR5 signaling and involve changes in excitatory circuitry. J Neurosci 31:14223-14234. CrossRef Medline

Higgs MH, Spain WJ (2011) Kv1 channels control spike threshold dynamics and spike timing in cortical pyramidal neurones. $J$ Physiol 589:5125-5142. CrossRef Medline

Hodgkin AL, Huxley AF (1952) A quantitative description of membrane current and its application to conduction and excitation in nerve. J Physiol 117:500-544. Medline

Hoffman DA, Johnston D (1999) Neuromodulation of dendritic action potentials. J Neurophysiol 81:408-411. Medline

Hutcheon B, yarom Y (2000) Resonance, oscillation and the intrinsic frequency preferences of neurons. Trends Neurosci 23:216-222. Medline

Jerng HH, Pfaffinger PJ, Covarrubias M (2004) Molecular physiology and modulation of somatodendritic A-type potassium channels. Mol Cell Neurosci 27:343-369. CrossRef Medline

Johnston D, Narayanan R (2008) Active dendrites: colorful wings of the mysterious butterflies. Trends Neurosci 31:309-316. CrossRef Medline

Kalmbach BE, Chitwood RA, Dembrow NC, Johnston D (2013) Dendritic generation of mGluR-mediated slow afterdepolarization in layer 5 neurons of prefrontal cortex. J Neurosci 33:13518-13532. CrossRef Medline

Kanai Y, Dohmae N, Hirokawa N (2004) Kinesin Transports RNA. Neuron 43:513-525. CrossRef Medline

Kim J, Nadal MS, Clemens AM, Baron M, Jung S-C, Misumi Y, Rudy $\mathrm{B}$, Hoffman DA (2008) Kv4 accessory protein DPPX (DPP6) is a critical regulator of membrane excitability in hippocampal CA1 pyramidal neurons. J Neurophysiol 100:1835-1847. CrossRef Medline

Kim J, Wei DS, Hoffman DA (2005) Kv4 potassium channel subunits control action potential repolarization and frequency-dependent broadening in rat hippocampal CA1 pyramidal neurones. J Physioly 569:41-57. CrossRef Medline

Kole MHP, Hallermann S, Stuart GJ (2006) Single /h channels in pyramidal neuron dendrites: properties, distribution, and impact on action potential output. J Neurosci 26:1677-1687. CrossRef Medline

Kole MHP, Letzkus JJ, Stuart GJ (2007) Axon initial segment Kv1 channels control axonal action potential waveform and synaptic efficacy. Neuron 55:633-647. CrossRef Medline

Korngreen A, Sakmann B (2000) Voltage-gated K+ channels in layer 5 neocortical pyramidal neurones from young rats: subtypes and gradients. J Physiol 525 Pt 3:621-639 Medline

Krueger DD, Osterweil EK, Chen SP, Tye LD, Bear MF (2011) Cognitive dysfunction and prefrontal synaptic abnormalities in a mouse model of fragile X syndrome. Proc Nat Acad Sci 108:25872592. CrossRef Medline

Lee AT, Gee SM, Vogt D, Patel T, Rubenstein JL, Sohal VS (2014) Pyramidal neurons in prefrontal cortex receive subtype-specific forms of excitation and inhibition. Neuron 81:61-68. CrossRef Medline

Lee HY, Ge W-P, Huang W, He Y, Wang GX, Rowson-Baldwin A, Smith SJ, Jan YN, Jan LY (2011) Bidirectional regulation of dendritic voltage-gated potassium channels by the fragile $X$ mental retardation protein. Neuron 72:630-642. CrossRef Medline

Li Z, Zhang Y, Ku L, Wilkinson KD, Warren ST, Feng Y (2001) The fragile $X$ mental retardation protein inhibits translation via interacting with mRNA. Nucleic Acids Res 29:2276-2283. Medline

London M, Häusser M (2005) Dendritic Computation. Annu Rev Neurosci 28:503-532. CrossRef Medline

Losonczy A, Makara JK, Magee JC (2008) Compartmentalized dendritic plasticity and input feature storage in neurons. Nature 452: 436-441. CrossRef Medline

Lörincz A, Notomi T, Tamás G, Shigemoto R, Nusser Z (2002) Polarized and compartment-dependent distribution of HCN1 in pyramidal cell dendrites. Nat Neurosci 5:1185-1193. CrossRef Medline

Magee JC (2000) Dendritic integration of excitatory synaptic input. Nat Rev Neurosci 1:181-190. CrossRef Medline

Menon V, Leroux J, White CD, Reiss AL (2004) Frontostriatal deficits in fragile $X$ syndrome: relation to FMR1 gene expression. Proc Nat Acad Sci 101:3615-3620. CrossRef Medline

Meredith RM, Holmgren CD, Weidum M, Burnashev N, Mansvelder HD (2007) Increased threshold for spike-timing-dependent plasticity is caused by unreliable calcium signaling in mice lacking fragile X gene Fmr1. Neuron 54:627-638. CrossRef Medline

Molnár Z, Cheung AFP (2006) Towards the classification of subpopulations of layer $\mathrm{V}$ pyramidal projection neurons. Neurosci Res 55:105-115. CrossRef Medline

Molyneaux BJ, Arlotta P, Menezes JRL, Macklis JD (2007) Neuronal subtype specification in the cerebral cortex. Nat Rev Neurosci 8:427-437. CrossRef Medline

Morishima M, Morita K, Kubota Y, Kawaguchi Y (2011) Highly differentiated projection-specific cortical subnetworks. J Neurosci 31: 10380-10391. CrossRef Medline

Narayanan R, Johnston D (2007) Long-Term potentiation in rat hippocampal neurons is accompanied by spatially widespread changes in intrinsic oscillatory dynamics and excitability. Neuron 56:1061-1075. CrossRef Medline

Otsuka T, Kawaguchi Y (2011) Cell diversity and connection specificity between callosal projection neurons in the frontal cortex. J Neurosci 31:3862-3870 CrossRef Medline

Patel AB, Hays SA, Bureau I, Huber KM, Gibson JR (2013) A target cell-specific role for presynaptic $\mathrm{Fmr} 1$ in regulating glutamate release onto neocortical fast-spiking inhibitory neurons. J Neurosci 33:2593-2604. CrossRef Medline 
Robinson RB, Siegelbaum SA (2003) Hyperpolarization-activated cation currents: from molecules to physiological function. Annu Rev Physiol 65:453-480. CrossRef Medline

Routh BN, Johnston D, Brager DH (2013) Loss of functional A-type potassium channels in the dendrites of CA1 pyramidal neurons from a mouse model of fragile X syndrome. J Neurosci 33:1944219450. CrossRef Medline

Russell SN, Publicover NG, Hart PJ, Carl A, Hume JR, Sanders KM, Horowitz B (1994) Block by 4-aminopyridine of a Kv1.2 delayed rectifier $\mathrm{K}+$ current expressed in Xenopus oocytes. J Physiol 481:571-584. CrossRef

Santoro MR, Bray SM, Warren ST (2012) Molecular mechanisms of fragile X syndrome: a twenty-year perspective. Annu Rev Pathol 7:219-245. CrossRef Medline

Sheets PL, Suter BA, Kiritani T, Chan CS, Surmeier DJ, Shepherd GMG (2011) Corticospinal-specific HCN expression in mouse motor cortex: /h-dependent synaptic integration as a candidate microcircuit mechanism involved in motor control. J Neurophysiol 106:2216-2231. CrossRef

Shepherd GMG (2013) Corticostriatal connectivity and its role in disease. Nat Rev Neurosci 14:278-291. CrossRef

Shin M, Brager D, Jaramillo TC, Johnston D, Chetkovich DM (2008) Mislocalization of $\mathrm{h}$ channel subunits underlies $\mathrm{h}$ channelopathy in temporal lobe epilepsy. Neurobiol Dis 32:26-36. CrossRef Medline

Stephens GJ, Garratt JC, Robertson B, Owen DG (1994) On the mechanism of 4-aminopyridine action on the cloned mouse brain potassium channel mKv1.1. J Physiol 477:187-196. CrossRef

Strumbos JG, Brown MR, Kronengold J, Polley DB, Kaczmarek LK (2010) Fragile $X$ mental retardation protein is required for rapid experience-dependent regulation of the potassium channel Kv3.1b. J Neurosci 30:10263-10271. CrossRef Medline

Testa-Silva G, Loebel A, Giugliano M, de Kock CPJ, Mansvelder HD, Meredith RM (2012) Hyperconnectivity and slow synapses during early development of medial prefrontal cortex in a mouse model for mental retardation and autism. Cerebral Cortex 22:1333-1342. CrossRef

Tyzio R, Nardou R, Ferrari DC, Tsintsadze T, Shahrokhi A, Eftekhari S, Khalilov I, Tsintsadze V, Brouchoud C, Chazal G, Lemonnier E, Lozovaya N, Burnashev N, Ben-Ari Y (2014) Oxytocin-mediated GABA inhibition during delivery attenuates autism pathogenesis in rodent offspring. Science 343:675-679. CrossRef Medline

Ulrich D (2002) Dendritic resonance in rat neocortical pyramidal cells. J Neurophysiol 87:2753-2759. Medline

Vaidya SP, Johnston D (2013) Temporal synchrony and gamma-totheta power conversion in the dendrites of CA1 pyramidal neurons. Nat Neurosci 16:1812-1820. CrossRef Medline

Wang JM, Koldewyn K, Hashimoto R-I, Schneider A, Le L, Tassone F, Cheung K, Hagerman P, HessI D, Rivera SM (2012) Male carriers of the FMR1 premutation show altered hippocampal-prefrontal function during memory encoding. Front Hum Neurosci 6. CrossRef

Zalfa F, Giorgi M, Primerano B, Moro A, Di Penta A, Reis S, Ben Oostra, Bagni $C$ (2003) The fragile $X$ syndrome protein FMRP associates with BC1 RNA and regulates the translation of specific mRNAs at synapses. Cell 112:317-327. Medline

Zhang Y, Bonnan A, Bony G, Ferezou I, Pietropaolo S, Ginger M, Sans N, Rossier J, Oostra B, LeMasson G, Frick A (2014) Dendritic channelopathies contribute to neocortical and sensory hyperexcitability in Fmr1. Nat Neurosci 1-12. 